\title{
Hydrogen Fuel Cell Development in Columbia (SC)
}

\author{
Ken Reifsnider, Principal Investigator \\ F. Chen, B. Popov, J. Van Zee, W. Chao. C. Xue, co-Principal Investigators \\ University of South Carolina \\ 300 Main Street \\ Columbia, SC 29208 \\ Phone: (803) 777-0084; Fax: (803)777-0106 \\ E-mail: Reifsnider@cec.sc.edu
}

Final Report

Prepared for the

\section{Department of Energy}

DOE Technology Development Manager:

DOE Project Officer: Reginald W. Tyler Phone: (303) 275-4925

E-mail: Reginald.tyler@go.doe.gov

Contract Number: DE-FG36-08GO88116

Project Start Date: July 31, 2008

Project End Date: July 31, 2012 


\section{Executive Summary}

This is an update to the final report filed after the extension of this program to May of 2011. The activities of the present program contributed to the goals and objectives of the Fuel Cell element of the Hydrogen, Fuel Cells and Infrastructure Technologies Program of the Department of Energy through five sub-projects. Three of these projects have focused on PEM cells, addressing the creation of carbon-based metal-free catalysts, the development of durable seals, and an effort to understand contaminant adsorption/reaction/transport/performance relationships at low contaminant levels in PEM cells. Two programs addressed barriers in SOFCs; an effort to create a new symmetrical and direct hydrocarbon fuel SOFC designs with greatly increased durability, efficiency, and ease of manufacturing, and an effort to create a multiphysics engineering durability model based on electrochemical impedance spectroscopy interpretations that associate the micro-details of how a fuel cell is made and their history of (individual) use with specific prognosis for long term performance, resulting in attendant reductions in design, manufacturing, and maintenance costs and increases in reliability and durability.

The principal accomplishments of the effort are listed below:

1. Metal-free oxygen reduction catalysts have been developed to reduce cost, facilitate manufacturing, and significantly enhance the durability of PEM fuel cells. Non-precious metal catalysts (NPMCs) were developed with exceptional activity and stability for oxygen reduction in alkaline electrolytes by introducing $\mathrm{N}$-based active sites on activated carbon

2. Redox stable mixed ionic and electronic conductors(MIECs) for bi-electrode supported cell (BSC) symmetrical (and other) SOFC designs have been developed. Hierarchically porous LSCF has been successfully prepared using a newly patented "self-rising" technique; LSGM samples were prepared and have shown promising conductivity in air; patent filed on the synthesis method developed during this program activity.

3. The development of durable, low cost seals for PEM stacks, through the establishment of laboratory characterization methodologies that relate to cell/stack performance has been achieved. Developed life prediction methodologies using WLF concepts; initial model development and verification for predicting compressive stress retained in seals under realistic temperature cycles

4. Understandings and methodologies have been developed to enable the establishment of hydrogen quality as it relates to PEM cell applications for transportation needs. A new model that describes partial recovery of performance indicative of simple sulfur based inorganic contaminants was completed. A procedure was proposed to determine all model rate constants. The model was used to predict a tolerance limit (worse case scenario) and the effect of a catalyst loading reduction.

5. First principles multiphysics durability models based on interpretations of Electrochemical Impedance Spectroscopy (EIS) data have been developed that form a foundation for engineering durability during design and manufacture of BSC SOFC fuel cell designs. A series of cathode and electrolyte materials have been successfully synthesized and characterized. CFD based multiphysics SOFC/SOEC models have been developed; A multi-physics model based mechanistic EIS simulation approach has been established for experimental data interpretation of degradation and prognosis of performance. 



\title{
Hydrogen Fuel Cell Development in Columbia (SC)
}

\author{
Ken Reifsnider, Principal Investigator \\ F. Chen, B. Popov, J. Van Zee, W. Chao. C. Xue, co-Principal Investigators \\ University of South Carolina \\ 300 Main Street \\ Columbia, SC 29208 \\ Phone: (803) 777-0084; Fax: (803)777-0106 \\ E-mail: Reifsnider@cec.sc.edu
}

\section{Objectives}

- Development of metal-free oxygen reduction catalysts to reduce cost, facilitate manufacturing, and enhance durability of fuel cells (Barriers A-C; Task 2 electrodes)

- Development of redox stable mixed ionic and electronic conductors (MIECs) for bi-electrode supported cell (BSC) symmetrical SOFC designs, to reduce cost by simplifying manufacturing, enhance durability, and greatly reduce sensitivity to thermal cycling (BarriersA-C,G; Tasks 8portable power, 11-innovative fuel cells, 10-long term failure mechanisms)

- Development of durable, low cost seals for PEM stacks, through the establishment of laboratory characterization methodologies that relate to cell/stack performance (BarriersA, C; Task 6 Seals)

- Development of understandings and methodologies to establish hydrogen quality as it relates to PEM cell applications for transportation needs (BarriersB,C,G; Tasks 9-models for impurities, 8portable operation)

- Development of a first principles multiphysics durability models based on interpretations of Electrochemical Impedance Spectroscopy (EIS) data that link the multiphysics processes, the microstructure, and the material states, with cell impedance responses and global performance, mechanistically, as a foundation for engineering durability during design and manufacture of fuel cells (BarriersA-G; Tasks 9-models, 10-long term failure mechanisms, 11-innovative fuel cell design and manufacture)

\section{Technical Barriers}

This project addressed the following technical barriers from section 3.4 of the Hydrogen, Fuel Cells and Infrastructure Technologies Program Multi-Year Research, Development and Demonstration Plan:

(A) Cost of PEM and SOFC fuel cells

(B) Durability of PEM and SOFC fuel cells

(C) Performance of PEM and SOFC fuel cells

(D) Transport in PEM cells

(E,F) Thermal and air management in SOFC fuel cells

(G) Transient operation 


\section{Technical Targets}

Carbon-based catalysts: To develop non-precious-metal catalysts for PEMFC with high selectivity and durability which perform as well as conventional Pt catalysts with a cost of at least $50 \%$ less than the target of $0.2 \mathrm{~g}$ (Pt loading)/ peak kW

SOFC materials: Develop SOFC electrode materials that enable direct operation on hydrocarbon fuels. Low-cost seals: Determine PEM seals materials that have no appreciable weight loss or leachants over a 60 week test period.

Hydrogen Contamination: Establish the rate and mechanism of $\mathrm{NH}_{3}$ transport in PEM cells over a 60 week period; identify the species of sulfur contamination on Pt catalysts in the presence of various gas species, e.g., $\mathrm{H}_{2} \mathrm{O}$ and $\mathrm{O}_{2}$.

Multiphysics based durability modeling: Use impedance spectroscopy to identify specific material state change driven degradation mechanisms during SOFC operation.

\section{Background for Approach}

1. Work on a previous DOE program, DE-FC36-03GO13108, was leveraged to create new carbonbased, metal-free catalysts for oxygen reduction.

2. Leveraged previous work in the SOFC SmartState Center at the University of South Carolina to develop new materials and materials designs to create a high performance SOFC that can directly operate on hydrocarbon fuels with high power density.

3. Recent advances at the University of South Carolina in controlled hydration and temperature characterization of polymer-based materials were used to establish a methodology for characterization of materials in seals in PEM stacks, and to develop a fundamental understanding how the degradation mechanisms of polymeric materials affects the performance and life of gasket/seals in PEMFC

4. On-going work with NREL, ANL, SRNL, and LANL formed a foundation for the work on developing an understanding of the contaminant adsorption/reaction/transport/ performance relationships at low contaminant levels in PEM cells. The study provided equilibrium and rate constants suitable for use in new and existing models, and in computer codes at Argonne National Laboratory.

5. Conceptual foundations laid by research supported by NSF, AFOSR and several industries including United Technologies Fuel Cells were expanded to create a multiphysics engineering durability model based on electrochemical impedance spectroscopy interpretations that associate the micro-details of how SOFC fuel cells are made and their history of individual use with long term performance, to achieve reductions in design, manufacturing and operating costs. 


\section{SubProject 1: \\ Development of Carbon Composite Electro- Catalyst for the Oxygen Reduction Reaction (ORR)}

\section{Branko Popov}

\section{Objectives}

- Synthesize carbon-based metal-free catalysts and carbon composite catalysts for ORR.

- Optimize catalytic active reaction sites as a function of carbon support, surface oxygen groups, nitrogen content, surface modifiers, pyrolysis temperature and porosity.

\section{Technical Barriers}

This project addresses the following technical barriers from the "Fuel Cells"

- Durability

- Cost

- Performance

\section{Technical Targets}

- Non-Pt catalyst activity per volume of supported catalyst $>130 \mathrm{~A} \mathrm{~cm}^{-3}$ (stack) at $0.8 \mathrm{iR}_{\text {free }}$

- Cost: at least $50 \%$ less than a target of $0.2 \mathrm{~g}$ (Pt loading)/peak kW

- Durability: $>2,000 \mathrm{~h}$ operation with less than $10 \%$ power degradation

\section{Accomplishments}

- The non-precious metal catalysts (NPMCs) with the exceptional activity and stability for oxygen reduction in alkaline electrolyte are developed by introducing $\mathrm{N}$-based active sites.

- The pyridinic-N and graphitic- $\mathrm{N}$ are believed to play important roles in the active sites of NPMCs.

- The NPMCs shows comparable performance with Pt/C in alkaline fuel cells with the open circuit potential of $0.97 \mathrm{~V}$ and maximum power density of $177 \mathrm{~mW} \mathrm{~cm}^{-2}$.

\section{Introduction}

Pt and Pt based alloy catalysts are widely used in PEMFCs because of their high catalytic activity and selectivity as well as high corrosion resistance. In the last few years, several transition metal compounds such as macrocycle-based metal porphyrin system, chevrel phase-type compounds and other transition 
metal chalcogenides have been proposed as selective catalysts for ORR. However, significant increase in activity and stability of the catalyst is still essential for PEMFC applications. The goal of this project is to develop highly active and stable carbon-based metal-free catalysts and carbon composite catalysts with strong Lewis basicity ( $\pi$ electron delocalization) to facilitate ORR.

We have systematically studied the activity and stability, as well as the nature of active sites of nonprecious metal catalysts (NPMCs) for the oxygen reduction reaction (ORR) [1-10]. In this work, the NPMC with high activity and stability in alkaline electrolyte was developed. The fuel cell performance of the catalyst was studied using anion exchange membrane (AEM) fuel cell.

\section{Approach}

The approach used to synthesize the catalyst includes the following steps: (i) the modification of a porous carbon black support; (ii) the deposition of Co-N or Co-Fe-N chelate complex on the support; (iii) the first high-temperature pyrolysis; (iv) the chemical post-treatment (acid leaching); and (v) the second hightemperature pyrolysis.

\section{Results}

Figure 1a shows polarization curves for oxygen reduction of NPMC heat-treated at $900{ }^{\circ} \mathrm{C}(\mathrm{NPMC}-900$ or $\mathrm{CoFeN} / \mathrm{C}-\mathrm{HLH}$ ) before and after potential cycling in $0.1 \mathrm{M} \mathrm{KOH}$. The cycling was performed in $\mathrm{N}_{2^{-}}$ saturated $0.1 \mathrm{M} \mathrm{KOH}$ with a scan rate of $10 \mathrm{mV} \mathrm{s}^{-1}$ between $0.8-1.2 \mathrm{~V}$ vs. RHE. The polarization curves were measured before and after 100, 200, and 700 cycles, respectively. It is evident that the NPMC-900 catalyst does not show any performance degradation during 700 cycles indicating that the catalyst is very stable in alkaline solution.

Figure $1 \mathrm{~b}$ shows the XPS spectra of $\mathrm{N}_{1 \mathrm{~s}}$ for the NPMC-900 before and after the potential cycling stability test in $0.1 \mathrm{M} \mathrm{KOH}$. The peaks of $\mathrm{N}_{1 \mathrm{~s}}$ at $398.6 \pm 0.3 \mathrm{eV}, 401.3 \pm 0.3 \mathrm{eV}$, and $403.3 \pm 0.3 \mathrm{eV}$ can be attributed to the pyridinic-N, graphitic- $\mathrm{N}$, and pyridine-N-oxide, respectively. The pyridinic-N and graphitic- $\mathrm{N}$ are believed to be active catalytic sites for oxygen reduction. As shown in Figure 1b, the profile of the $\mathrm{N}_{1 \mathrm{~s}}$ spectra of NPMC-900 is still similar to that of fresh catalyst indicating high stability of NPMC for oxygen reduction in alkaline electrolytes.

The kinetic parameters for oxygen reduction reaction on $\mathrm{CoFeN} / \mathrm{C}$ subject to heat-treatment, leaching, and re-heat-treatment $(\mathrm{CoFeN} / \mathrm{C}-\mathrm{HLH})$ and $\mathrm{Pt} / \mathrm{C}$ catalysts including the ring currents, the numbers of electron exchanged and polarization curves were obtained using RRDE system in $\mathrm{O}_{2}$-saturated $0.1 \mathrm{M}$ $\mathrm{KOH}$. Figure 2 summarizes the RRDE results. The data of carbon black are also presented for comparison. The ring currents were measured on Pt ring electrode held at $1.2 \mathrm{~V}$ for CoFeN/C-HLH and $\mathrm{Pt} / \mathrm{C}$ catalysts. It is evident that the ring currents for $\mathrm{CoFeN} / \mathrm{C}-\mathrm{HLH}$ and $\mathrm{Pt} / \mathrm{C}$ are comparable. In contrast, the ring current for carbon is much higher. The number of electrons exchanged in the redox reaction for $\mathrm{CoFeN} / \mathrm{C}-\mathrm{HLH}$ and $\mathrm{Pt} / \mathrm{C}$ is 3.9-4.0 at high potentials.

The results indicate that both $\mathrm{CoFeN} / \mathrm{C}-\mathrm{HLH}$ and Pt/C catalysts catalyze the ORR mainly via a fourelectron pathway in alkaline electrolyte. For carbon black alone, a lower selectivity with number of electrons exchanged in the range of 3.3-3.6 was observed at high potentials. The catalytic performance of $\mathrm{CoFeN} / \mathrm{C}-\mathrm{HLH}$ is comparable with $\mathrm{Pt} / \mathrm{C}$ for oxygen reduction in alkaline electrolytes.

Figure 3 shows the preliminary performance of a $\mathrm{H}_{2}-\mathrm{O}_{2}$ anion exchange membrane (AEM) fuel cell. The operation temperature is $50^{\circ} \mathrm{C}$. The Pt loading at anode is $0.4 \mathrm{mg} \mathrm{cm}^{-2}$, whereas the catalyst loadings at cathode are $4 \mathrm{mg} \mathrm{cm}^{-2}$ for CoFeN/C-HLH and $0.4 \mathrm{mg}_{\mathrm{Pt}} \mathrm{cm}^{-2}$ for $\mathrm{Pt} / \mathrm{C}$. Anode and cathode gases are humidified at $50{ }^{\circ} \mathrm{C}$. The flow rates of $\mathrm{H}_{2}$ and $\mathrm{O}_{2}$ are 200 and $400 \mathrm{~mL} \mathrm{~min}^{-1}$. The open circuit potentials are 0.97 and $1.04 \mathrm{~V}$ for $\mathrm{CoFeN} / \mathrm{C}-\mathrm{HLH}$ and $\mathrm{Pt} / \mathrm{C}$, respectively. The maximum power densities are 177 and $196 \mathrm{~mW} \mathrm{~cm}{ }^{-2}$ for $\mathrm{CoFeN} / \mathrm{C}-\mathrm{HLH}$ and $\mathrm{Pt} / \mathrm{C}$, respectively. At high potential, the performance of 
CoFeN/C-HLH is slightly lower than Pt/C. At intermediate potential, they show very similar performance. The lower performance of $\mathrm{CoFeN} / \mathrm{C}-\mathrm{HLH}$ over $\mathrm{Pt} / \mathrm{C}$ at low potential may be attributed to higher mass-transfer resistance of the former resulting from higher catalyst loading and thus higher thickness of catalyst layer.

\section{Conclusions}

- Non-precious metal catalysts (NPMCs) for oxygen reduction in alkaline electrolyte are developed by heating metal-nitrogen containing chelates followed by chemical post-treatment.

- The pyridinic-N and graphitic-N supported on graphitized carbon are active sites for oxygen reduction with high stability in alkaline electrolytes.

- The NPMCs exhibits comparable performance with Pt/C in anion exchange membrane fuel cells with the open circuit potential of $0.97 \mathrm{~V}$ and maximum power density of $177 \mathrm{~mW} \mathrm{~cm}$.

\section{Figure Captions}

Figure 1a. Polarization curves for the oxygen reduction reaction in $\mathrm{O}_{2}$-saturated $0.1 \mathrm{M} \mathrm{KOH}$ of nonprecious metal catalysts heat-treated at $900{ }^{\circ} \mathrm{C}$ before and after the potential cycling stability test; scan rate: $5 \mathrm{mV} \mathrm{s}^{-1}$; rotation rate: $900 \mathrm{rpm}$.

Figure 1b. XPS spectra of N1s obtained for: (a) fresh non-precious metal catalyst and for catalyst cycled 700 cycles in $0.1 \mathrm{M} \mathrm{KOH}$.

Figure 2 Comparison of $\mathrm{CoFeN} / \mathrm{C}-\mathrm{HLH}$ and $\mathrm{Pt} / \mathrm{C}$ catalysts for the oxygen reduction reaction in $\mathrm{O}_{2^{-}}$ saturated $0.1 \mathrm{M} \mathrm{KOH}$. Scan rate: $5 \mathrm{mV} \mathrm{s}^{-1}$; rotation rate: $900 \mathrm{rpm}$. (a) Ring currents; (b) the number of electron exchanged during oxygen reduction; (c) polarization curves.

Figure 3. Preliminary performance of a $\mathrm{H}_{2}-\mathrm{O}_{2}$ anion exchange membrane fuel cell. The operation temperature is $50^{\circ} \mathrm{C}$. The $\mathrm{Pt}$ loading at anode is $0.4 \mathrm{mg} \mathrm{cm}^{-2}$, whereas the catalyst loadings at cathode are $4 \mathrm{mg} \mathrm{cm}^{-2}$ for CoFeN/C-HLH and $0.4 \mathrm{mg}_{\mathrm{Pt}} \mathrm{cm}^{-2}$ for Pt/C. Anode and cathode gases are humidified at $50^{\circ} \mathrm{C}$. The flow rates of $\mathrm{H}_{2}$ and $\mathrm{O}_{2}$ are 200 and $400 \mathrm{~mL} \mathrm{~min}^{-1}$.

\section{Example Publications:}

1. G. Liu, X. Li, P. Ganesan, B. N. Popov, "Studies of oxygen reduction reaction active sites and stability of nitrogen-modified carbon composite catalysts for PEM fuel cells", Electrochimica Acta, 55 (2010) 2853-2858.

2. X. Li, S. Park, B. N. Popov, "Highly stable Pt and PtPd hybrid catalysts supported on a nitrogenmodified carbon composite for fuel cell application", Journal of Power Sources, 195 (2010) $445-452$.

3. X. Li, G. Liu, B. N. Popov, "Activity and stability of non-precious metal catalysts for oxygen reduction in acid and alkaline electrolytes", Journal of Power Sources, 195 (2010) 6373-6378.

4. B. N. Popov, X. Li and J. W. Lee, "Power source research at USC: Development of advanced electrocatalysts for polymer electrolyte membrane fuel cells", International Journal of Hydrogen Energy, 36 (2011) 1794-1802.

5. X. Li, B. N. Popov, T. Kawahara and H. Yanagi, "Non-precious metal catalysts synthesized from precursors of carbon, nitrogen and transition metal for oxygen reduction in alkaline fuel cells", Journal of Power Sources, 196 (2011) 1717-1722. 


\section{Conference Proceedings}

1. G. Liu, X. Li, B. N. Popov, "Stability study of nitrogen-modified carbon composite catalysts for oxygen reduction reaction in polymer electrolyte membrane fuel cells", ECS Transactions (2009), 25(1, Protein Exchange Membrane Fuel Cells 9), 1251-1259.

2. X. Li, S. Huang, B. N. Popov, "Development of Low Pt Loading Cathode Catalysts for Polymer Electrolyte Membrane Fuel Cells", ECS Trans. 2010, 33, 239-246.

3. X. Li and B. N. Popov, "Development of Non-Precious Metal Catalysts for Oxygen Reduction Reaction in Fuel Cells with High Activity and Stability", ECS Trans. 2010, 33, 2333-2339. 


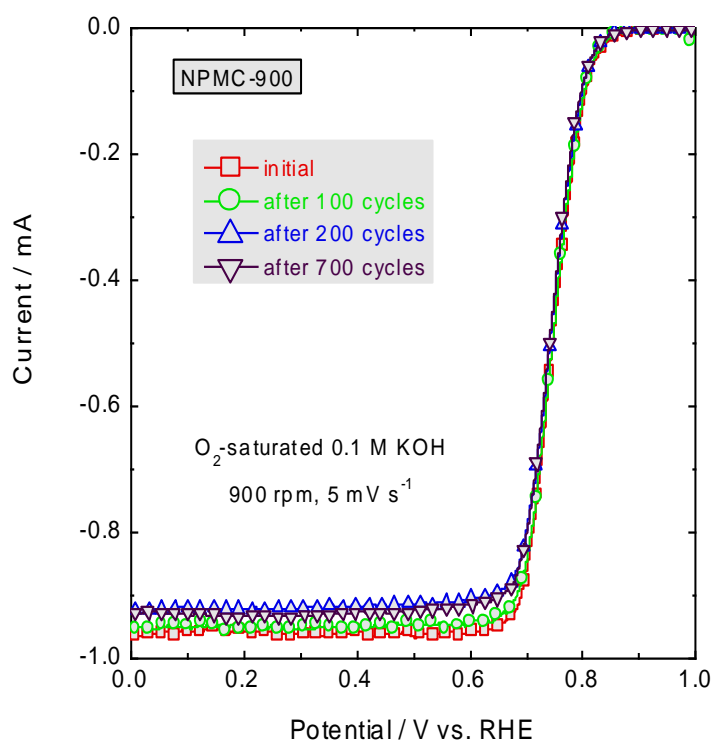

Fig. 1.a

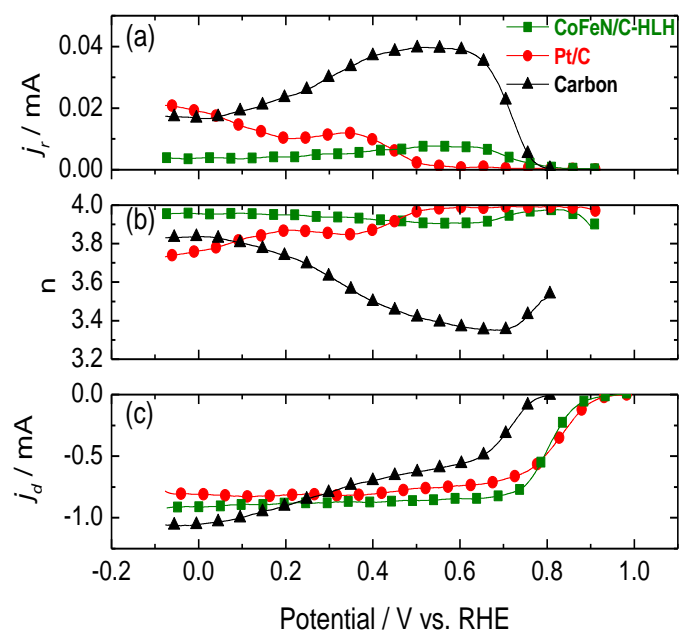

Fig. 2

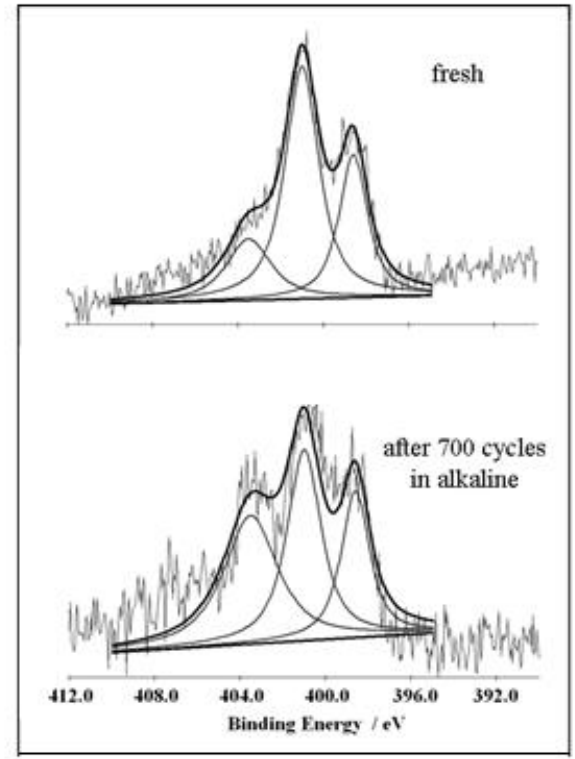

Fig. 1.b

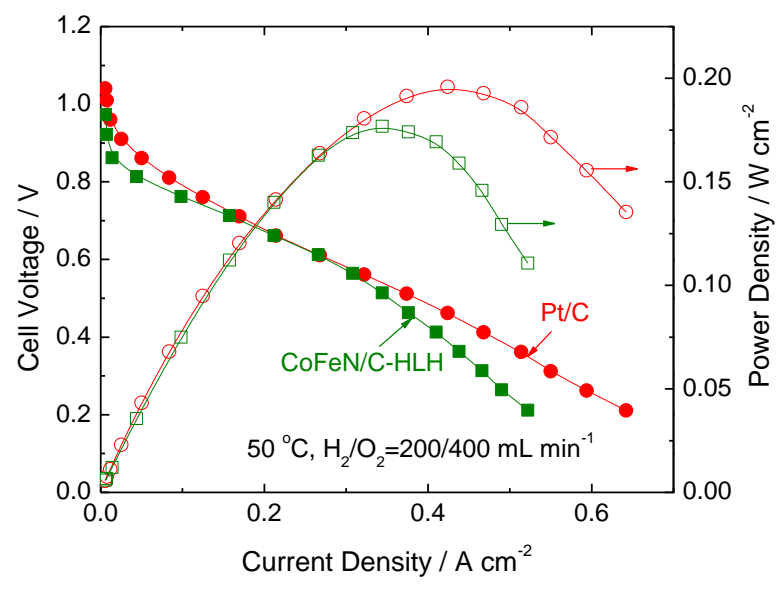

Fig. 3 


\section{Sub-Project 2: Hydrocarbon Fuel Powered High Power Density SOFC}

\section{Frank Chen \\ Department of Mechanical Engineering University of South Carolina}

This main focus of this project was to develop a high performance solid oxide fuel cell (SOFC) which can directly operate on hydrocarbon fuels and achieve high power density. In order to meet this goal, the experiments are designed with the following tasks:

- Infiltrate ceria to conventional Ni-based anode to mitigate coking.

- Develop mixed ionic and electronic conducting electrode materials.

- Develop anode materials which are capable of direct utilization of hydrocarbon fuels with tolerance to carbon formation and sulfur poisoning.

- Demonstrate high power density SOFCs using hydrocarbon fuels

A schematic of a Ni based anode-supported cell with $\mathrm{Sm}$ doped ceria (SDC, $\mathrm{Sm}_{0.2} \mathrm{Ce}_{0.8} \mathrm{O}_{1.9}$ ) electrolyte and infiltrated nanoparticles within the co-sintered electrodes is shown in Figure 1. For the Ni-SDC anode, the infiltrated particles could be ionic conductive materials. While at the cathode side, SDC could be the cathode skeleton material since it had no reaction with the electrolyte in the co-sintering process. Since SDC has high ionic conductivity, the electronic conductive materials or mixed ionic and electronic conductors were suitable for the infiltrated particles to increase the electronic conductivity of the cathode.

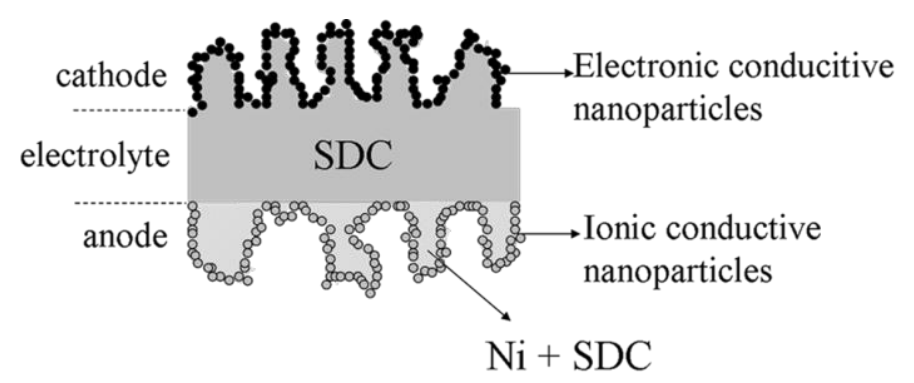

Figure 1. Schematic diagram of an anode-supported cell with infiltrated electrodes

The anode is based on the traditional $\mathrm{Ni}$ as an electronic conducting backbone covered with doped ceria. Ni particles can be covered with doped ceria using infiltration method to reduce their activities for carbon formation. And nickel is used as the backbones to ensure electronic conduction and to make the co-firing technique applicable to SOFC fabrication. At the same time, doped ceria, which is also a good anode material for direct electrochemical oxidation of methane and a good catalyst to remove carbon, is used to coat nickel to block hydrocarbon from accessing to Ni surface (5). The infiltrated anode is shown in Figure 2. 

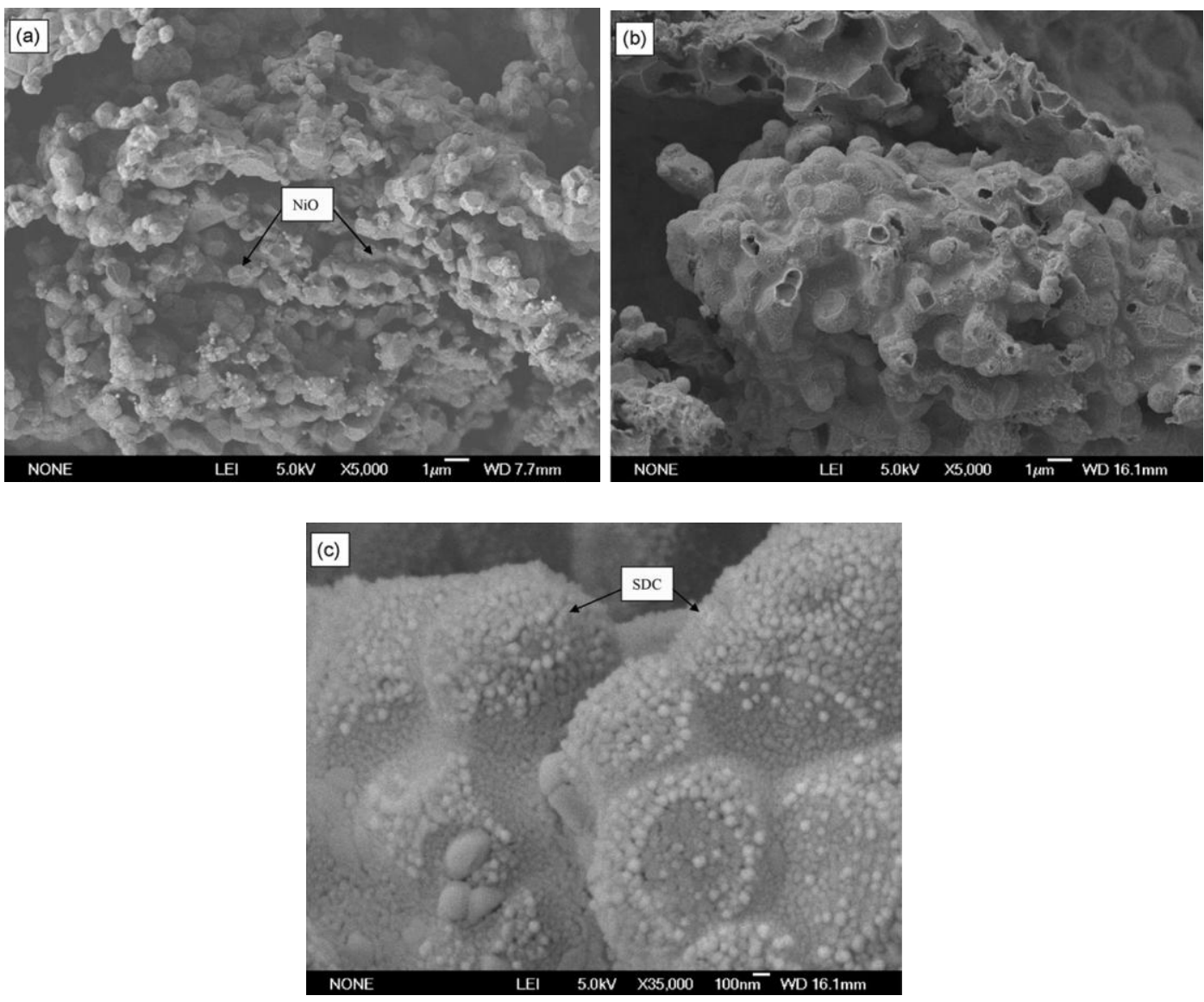

Figure 2. SEM micrographs for SDC infiltrated anode: a) Ni skeleton, b) anode with the infiltrated SDC loading of $648 \mathrm{mg} \mathrm{cm}^{-3}$, and c) high magnification for b).

The optimized single cells with SDC infiltrated anodes were investigated when hydrocarbons were used as the fuels. The stability of the cells with different SDC infiltrated loadings were investigated with humidified methane as fuel (shown in Figure 3). No significant degradation was observed for anode infiltrated by 20 and $25 \mathrm{mg} \mathrm{cm}^{-2}$ SDC. This verified that the SDC infiltrated anodes were very effective in suppressing catalytic carbon formation by blocking methane from approaching the $\mathrm{Ni}$, which is catalytically active towards methane pyrolysis. The high performance of infiltrated anode showed high promise in the developing field of direct hydrocarbon SOFCs.

The optimized single cells with SDC infiltrated anodes were investigated when hydrocarbons were used as the fuels. The stability of the cells with different SDC infiltrated loadings were investigated with humidified methane as fuel (shown in Figure 3). No significant degradation was observed for anode infiltrated by 20 and $25 \mathrm{mg} \mathrm{cm}^{-2}$ SDC. This verified that the SDC infiltrated anodes were very effective in suppressing catalytic carbon formation by blocking methane from approaching the $\mathrm{Ni}$, which is catalytically active towards methane pyrolysis. The high performance of infiltrated anode showed high promise in the developing field of direct hydrocarbon SOFCs. 


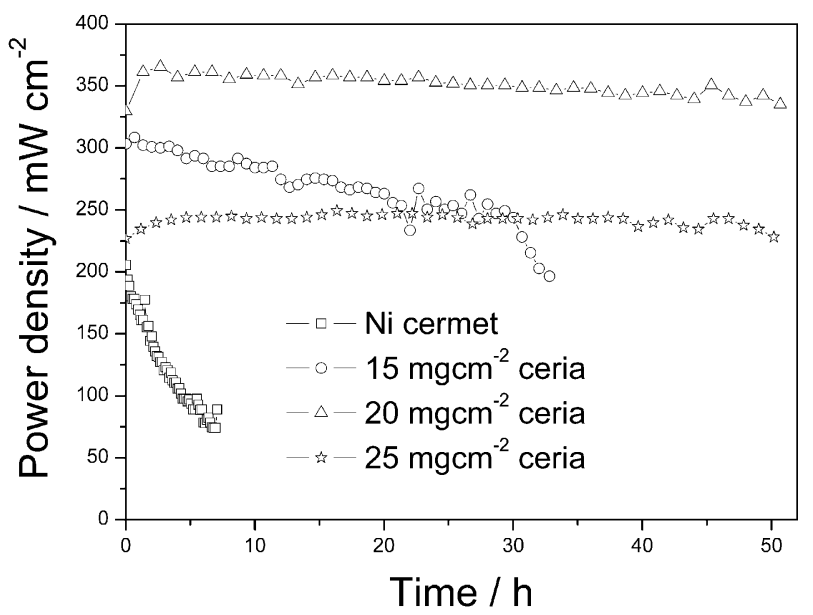

Figure 3. Time dependence of power densities for cells with different SDC loaded anodes operated at $600^{\circ} \mathrm{C}$ with a constant output voltage of $0.5 \mathrm{~V}$.

Mixed ionic and electronic conductors (MIECs) have recently been explored as anode materials for direct-hydrocarbon SOFCs. However, the electrical conductivity and the catalytic activity of the most reported MIEC ceramics are still not satisfactory. Without precious metal catalysts, the cell performances are limited, especially when directly operated with hydrocarbon fuels. Recently, a novel perovskite $\mathrm{Sr}_{2} \mathrm{Fe}_{1.5} \mathrm{Mo}_{0.5} \mathrm{O}_{6}$ (SFMO) has been reported to show high electrochemical performance as anode material in SOFCs operating with hydrogen as fuel and the relatively high electrical conductivity may potentially promote the catalytic activity of other metallic catalysts. Accordingly, dispersing a small amount of Ni on the SFMO anode as catalyst may be expected to improve the anode performance while avoiding carbon deposition from the conventional Ni-cermet anode for direct methane SOFCs.

In this study, $\mathrm{La}_{0.8} \mathrm{Sr}_{0.2} \mathrm{Ga}_{0.83} \mathrm{Mg}_{0.17} \mathrm{O}_{3}$ (LSGM) electrolyte supported single cells with $\mathrm{La}_{0.6} \mathrm{Sr}_{0.4} \mathrm{Co}_{0.2} \mathrm{Fe}_{0.8} \mathrm{O}_{3}$ (LSFC) as the cathode and Ni-modified SFMO as the anode were fabricated and tested for direct utilization of methane fuel. The reason for using SFMO as anode material is its high electrical conductivity and redox stability. A small amount of $\mathrm{NiO}(\sim 2 \mathrm{wt} \%)$ was applied to modify the performance of the ceramic anode by infiltrating the SFMO anode with nickel nitrate solution followed by heat-treatment. The chemical stability between $\mathrm{NiO}$ and SFMO, the single cell performance as well as the cell performance stability of the Ni-modified SFMO anode using wet $\mathrm{CH}_{4}\left(3 \% \mathrm{H}_{2} \mathrm{O}\right)$ as fuel were evaluated.

The chemical stability between SFMO and $\mathrm{NiO}$ was investigated by firing the mixed powders of SFMO and $\mathrm{NiO}\left(50: 50 \mathrm{wt} \%\right.$ ) at $1000^{\circ} \mathrm{C}$ for $10 \mathrm{~h}$ in air. The XRD pattern of the mixed powder is shown in Figure 4. Only XRD peaks corresponding to those of $\mathrm{NiO}$ and SFMO are present, indicating that there is no chemical compatibility issue for Ni modified SFMO anode under the cell operating conditions. 


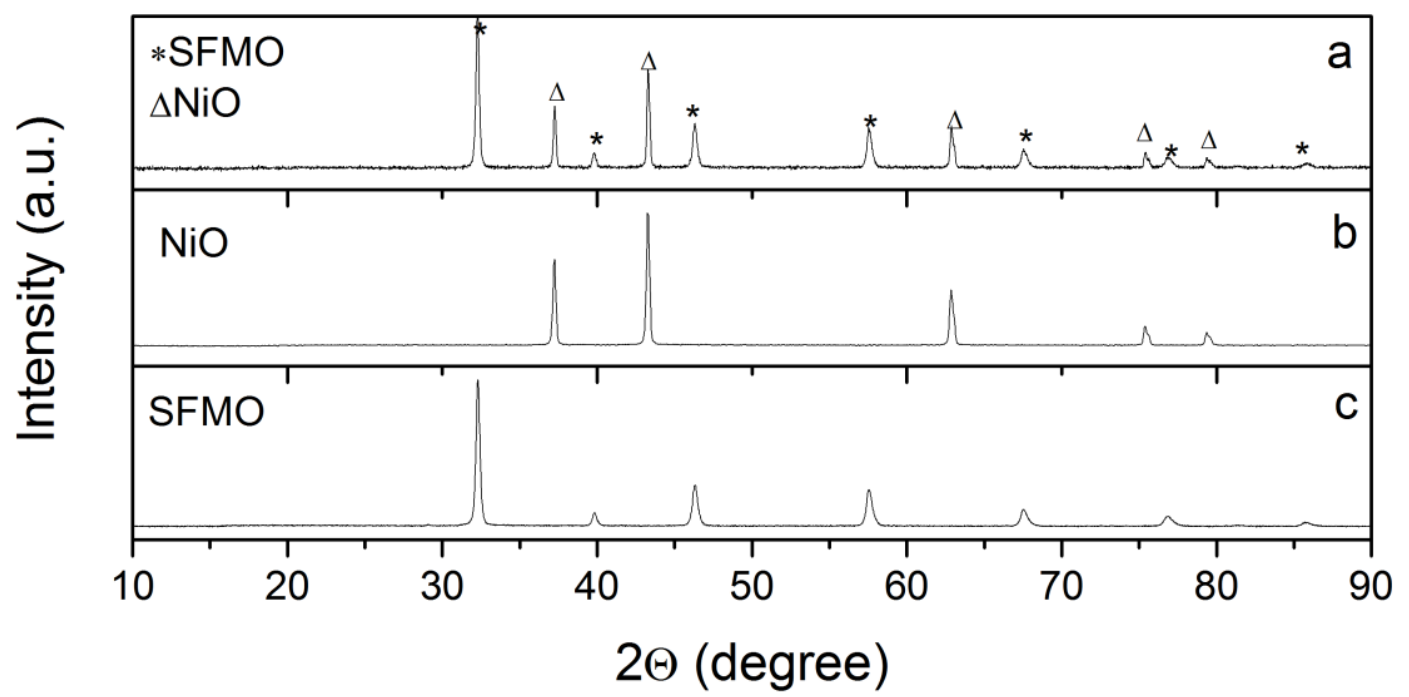

Figure 4. XRD patterns of (a) the mixed powders of SFMO and $\mathrm{NiO}(50: 50 \mathrm{wt} \%$ ) fired at $1000 \mathrm{oC}$ for $10 \mathrm{~h}$ in air, (b) $\mathrm{NiO}$ and (c) SFMO

The performance of the fuel cells with either Ni-SFMO anode or SFMO anode at $800^{\circ} \mathrm{C}$ is shown in Figure 5. It can be seen that introduction of small amount of Ni phase in the SFMO anode has significantly enhanced the cell performance in both $\mathrm{H}_{2}$ and $\mathrm{CH}_{4}$. With the ambient air as the oxidant, the peak power density of the fuel cells with $\mathrm{t}$ SFMO as anode is $0.291 \mathrm{~W} \mathrm{~cm}^{-2}$ in wet $\mathrm{H}_{2}\left(3 \mathrm{vol} \% \mathrm{H}_{2} \mathrm{O}\right)$ and only $0.033 \mathrm{~W} \mathrm{~cm}^{-2}$ in wet $\mathrm{CH}_{4}\left(3 \mathrm{vol} \% \mathrm{H}_{2} \mathrm{O}\right)$ at $800^{\circ} \mathrm{C}$. It is noticed that the $\mathrm{OCV}$ of the cell drops to $0.68 \mathrm{~V}$ with wet $\mathrm{CH}_{4}\left(3 \mathrm{vol} \% \mathrm{H}_{2} \mathrm{O}\right)$ as the fuel, indicating the low catalytic activity of the SFMO material to $\mathrm{CH}_{4}$. With the same testing conditions, the peak power density of fuel cells with Ni-SFMO as anode reaches $1.134 \mathrm{~W} \mathrm{~cm}^{-2}$ in wet $\mathrm{H}_{2}\left(3 \mathrm{vol} \% \mathrm{H}_{2} \mathrm{O}\right)$ and $0.669 \mathrm{~W} \mathrm{~cm}^{-2}$ in wet $\mathrm{CH}_{4}\left(3 \mathrm{vol} \% \mathrm{H}_{2} \mathrm{O}\right)$. The OCV of the cells with the Ni-SFMO anode in wet $\mathrm{CH}_{4}$ is $1.08 \mathrm{~V}$, suggesting that the catalytic activity of the SFMO anode is greatly improved by loading a small amount of Ni catalyst in the SFMO phase. The performance of cells with the NiSFMO anode in $\mathrm{H}_{2}$ and $\mathrm{CH}_{4}$ is much higher than those of fuel cells with the ceramic anodes ever reported (e.g. the highest reported peak power density of cells is $0.735 \mathrm{~W} \mathrm{~cm}^{-2}$ in $\mathrm{H}_{2}$ with the $\mathrm{Sr}_{2} \mathrm{CoMoO}_{6}$ anode and $0.55 \mathrm{~W} \mathrm{~cm}{ }^{-2}$ in wet $\mathrm{CH}_{4}\left(3 \mathrm{vol} \% \mathrm{H}_{2} \mathrm{O}\right)$ with the $\mathrm{Sr}_{1.2} \mathrm{La}_{0.8} \mathrm{MgMoO}_{6}$ anode at $800^{\circ} \mathrm{C}$ ). High performance of the Ni-SFMO anode is probably due to not only the catalytic activity of the highly dispersed Ni particles, but also the high electrical conductivity and good electrochemical activity of the SFMO ceramics. 


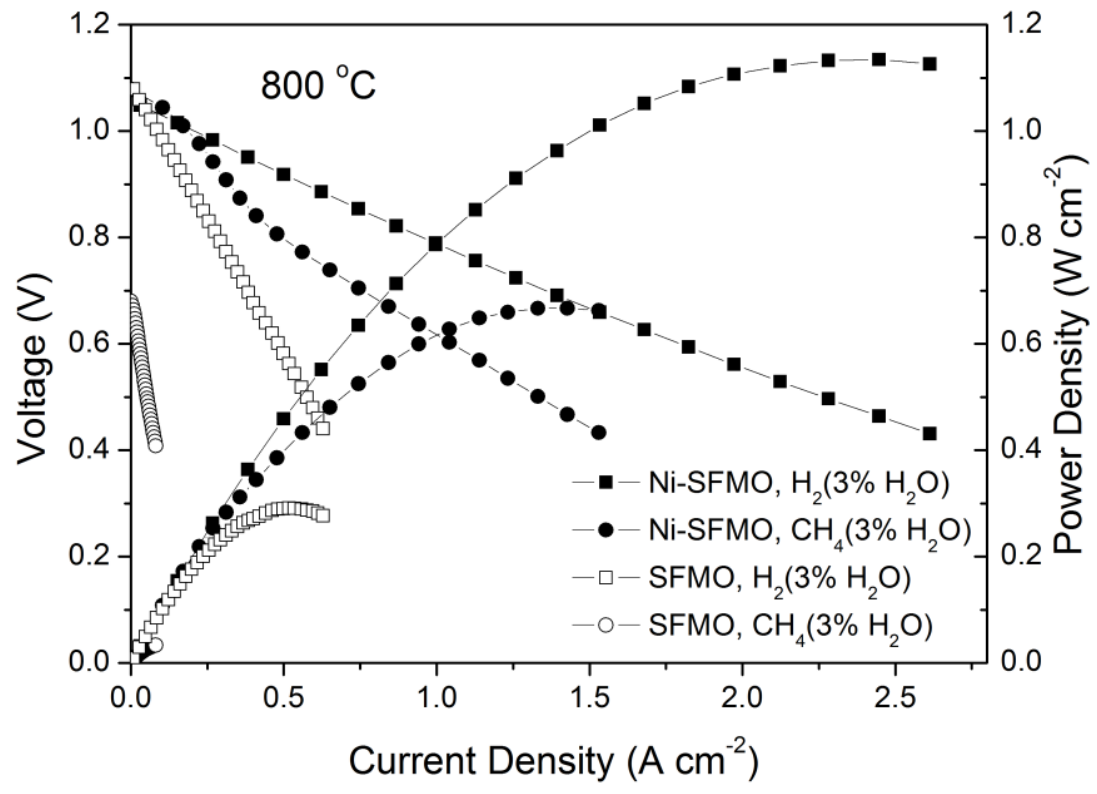

Figure 5. Voltage and power densities of the cells with either Ni-SFMO anode or SFMO anode tested using $\mathrm{H}_{2}\left(3 \mathrm{vol} \% \mathrm{H}_{2} \mathrm{O}\right)$ and $\mathrm{CH}_{4}\left(3 \mathrm{vol} \% \mathrm{H}_{2} \mathrm{O}\right)$ as fuel at $800^{\circ} \mathrm{C}$ with ambient air as the oxidant.

The performance stability of cells with the Ni-SFMO anode in $\mathrm{CH}_{4}$ was investigated by recording the current density of the cell operating at $0.7 \mathrm{~V}$ at $800^{\circ} \mathrm{C}$. As shown in Figure $6 a$, the cell performance is very stable in the tested period, indicating that Ni-SFMO anode has excellent catalytic activity and stability when directly operating on $\mathrm{CH}_{4}$ fuel. The stability of the cell is further confirmed by the impedance spectra of the cells measured under open circuit conditions in $\mathrm{CH}_{4}$ before and after the performance stability test. Very similar impedance spectra are obtained, indicating that Ni modified SFMO anode has good stability and no significant carbon deposition occurred upon operating the cell directly with $\mathrm{CH}_{4}$ fuel. This result would be attributed to the enlarged reaction sites on the SFMO oxide and the high dispersion of fine Ni particles which may accelerate the anode electrochemical reactions and suppress carbon formation on the confined Ni surfaces. 


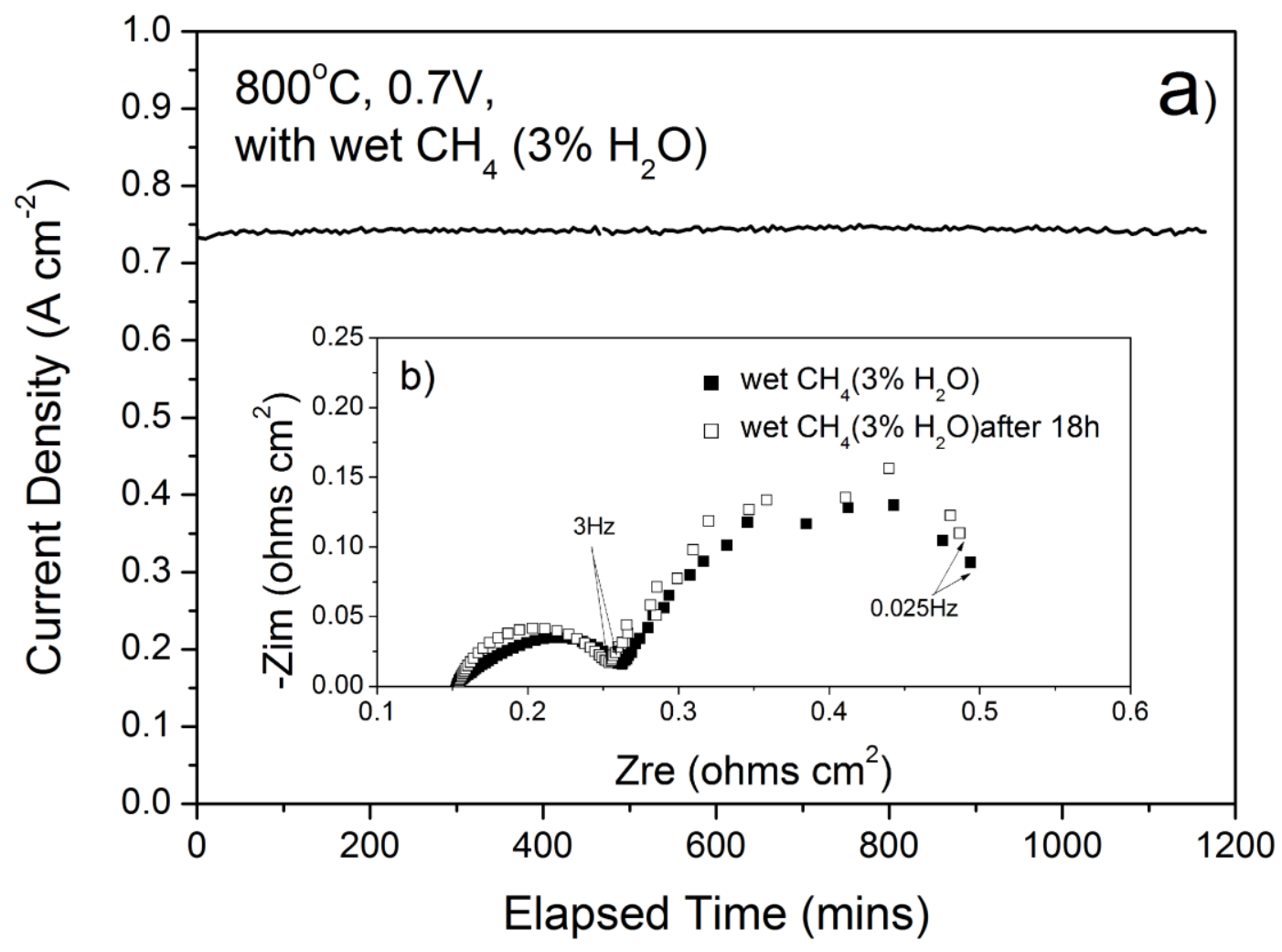

Figure 6. (a) Dependence of the current density as a function of the operating time of the cells with Ni-SFMO anode operated in $\mathrm{CH}_{4}\left(3 \mathrm{vol} \% \mathrm{H}_{2} \mathrm{O}\right)$ at cell voltage of $0.7 \mathrm{~V}$ at $800^{\circ} \mathrm{C}$ and (b) the impedance spectra of the cell before and after operating in $\mathrm{CH}_{4}\left(3 \mathrm{vol} \% \mathrm{H}_{2} \mathrm{O}\right)$ at cell voltage of $0.7 \mathrm{~V}$ at $800^{\circ} \mathrm{C}$ for $18 \mathrm{~h}$.

\begin{tabular}{|c|c|c|c|c|c|c|c|c|}
\hline \multirow{2}{*}{$\frac{\mathrm{I}}{\mathrm{H}^{1}}$} & \multirow[t]{2}{*}{ II } & \multirow{2}{*}{\multicolumn{4}{|c|}{$\mathrm{La}_{\mathbf{0 . 8}} \mathrm{Sr}_{\mathbf{0 . 2}} \mathrm{Ga}_{0.5} \mathrm{Mn}_{\mathbf{0 . 5}} \mathbf{O}_{3}$}} & \multirow[t]{2}{*}{\begin{tabular}{|l|} 
III \\
\end{tabular}} & \multirow[t]{2}{*}{ IV } & \multirow[t]{2}{*}{$\mathrm{V}$} \\
\hline & & & & & & & & \\
\hline $\mathrm{Li}^{3}$ & $B e^{4}$ & \multicolumn{4}{|c|}{ Transition Metals } & $B^{5}$ & \begin{tabular}{l|l}
$C^{6}$ & 1 \\
\end{tabular} & $N^{7}$ \\
\hline $\mathrm{Na}^{11}$ & $\mathrm{Mg}^{12}$ & IIIB IVB VB VIB & $\mathrm{VIIB}$ & $\mathrm{VIIIB}$ & IB $\quad$ IIB & $\mathrm{Al}^{13}$ & $\mathrm{Si}^{14} \mathrm{H}$ & $P^{15}$ \\
\hline$K^{19}$ & $\mathrm{Ca}^{20}$ & $\mathrm{Sc}^{21} \mathrm{Ti}^{22} \mathrm{~V}^{23} \mathrm{Cr}^{24}$ & $\mathrm{Mn}^{23} \mathrm{Fe}^{26}$ & $\begin{array}{ll}\mathrm{CO}^{27} & \mathrm{Ni} \\
\end{array}$ & \begin{tabular}{|l|l}
$\mathrm{Cu}^{20}$ & $\mathrm{Zn}^{30}$ \\
\end{tabular} & (Ga) & $\mathrm{Ge}$ & $\mathrm{As}^{33}$ \\
\hline$R b^{37}$ & $\mathrm{Sr}^{39}$ & 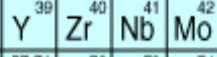 & $T_{C}^{43} \mathrm{Ru}^{44}$ & $\mathrm{Rh}^{45} \mathrm{Pd}$ & $\mathrm{Ag}^{47} \mathrm{Cd}$ & $\ln$ & $\mathrm{Sn}^{50} S$ & $\mathrm{Sb}^{51}$ \\
\hline Cs & $\mathrm{Ba}^{56}$ & $\stackrel{57}{57}^{57}\left|\mathrm{Hf}^{72}\right| \mathrm{Ta}^{73} \mid \mathrm{W}^{74}$ & $\operatorname{Re}^{75} \mid \mathrm{OS}^{76}$ & $\operatorname{li}^{77} \mid \mathrm{Pt}$ & \begin{tabular}{|l|l|l}
$u^{79}$ & ${ }^{80}$ \\
\end{tabular} & $\mid \mathrm{TI}^{88}$ & $\mathrm{~Pb}^{82} \mathrm{E}_{\mathrm{E}}$ & $B i^{80}$ \\
\hline & & & Mn & Ga & Mg & $\mathrm{Sr}$ & & La \\
\hline Elen & nent & radius $(\mathrm{pm})$ & 127 & 135 & 160 & 215 & & 187 \\
\hline $1+\mathrm{ic}$ & on $\mathrm{r}$ & adius (pm) & & 81 & & & & 139 \\
\hline $2+\mathrm{ic}$ & on $\mathrm{r}$ & adius (pm) & 80 & & 66 & 112 & & \\
\hline $3+\mathrm{i}$ & on & & 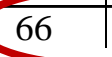 & 62 & & & & 102 \\
\hline
\end{tabular}

- $\mathrm{La}_{0.8} \mathrm{Sr}_{0.2} \mathrm{Ga}_{0.8} \mathrm{Mg}_{0.2} \mathrm{O}_{3}$ (LSGM) is an excellent ionic conductor

- $\mathrm{La}_{0.8} \mathrm{Sr}_{0.2} \mathrm{Ga}_{0.5} \mathrm{Mn}_{0.5} \mathrm{O}_{3}$ (LSGMn) potential mixed conducting anode

- Introducing electronic conduction while maintaining ionic conduction 
Figure 7 shows the fuel cell performance of the electrolyte-support single fuel cell at different operating temperatures. The maximum open cell potential is about $1.08 \mathrm{~V}$ at $650^{\circ} \mathrm{C}$ in humidified $\mathrm{H}_{2}$, and this value decreases with the increase in the cell testing temperature. The higher conductivity will result in lower resistance polarization and hence higher performance. The peak power density reached $400 \mathrm{~mW} \mathrm{~cm}^{-2}$ at $800{ }^{\circ} \mathrm{C}$, despite the relative thick electrolyte $(400 \mu \mathrm{m})$. It is expected that further performance improvement can be obtained by decreasing the electrolyte thickness or optimizing the microstructure of the LSGMn anodes.

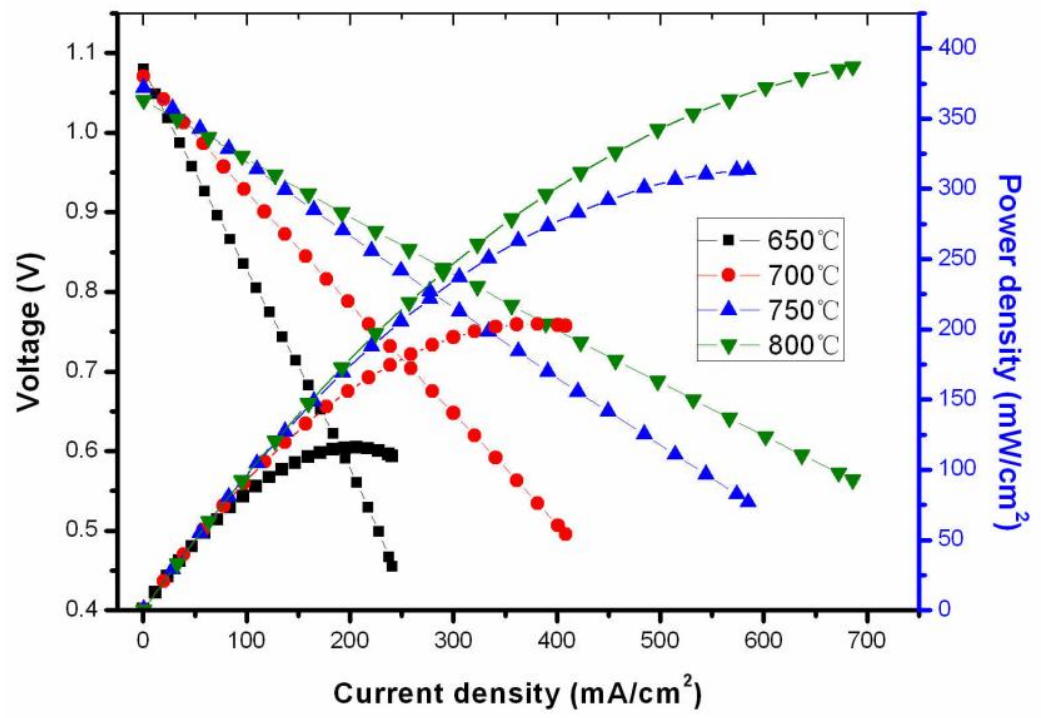

Figure 7. Fuel cell performance for cell with LSGMn as anode

Shown in Figure 8 are the impedance spectra for the cell operated at different temperatures, indicating that the total impedance decreases with the increase of the cell operating temperature from $650^{\circ} \mathrm{C}$ to $800^{\circ} \mathrm{C}$. The intercept of high-frequency arc with the real axis is related to the ohmic resistance of the cell, mainly the resistance of the electrolyte, while the difference between the real axis intercepts of the impedance is due to the interfacial polarization resistance. With the increase of the operating temperature, both the ohmic and interfacial polarization resistances decrease, resulting in improvement of cell performance, as shown in Figure 8.

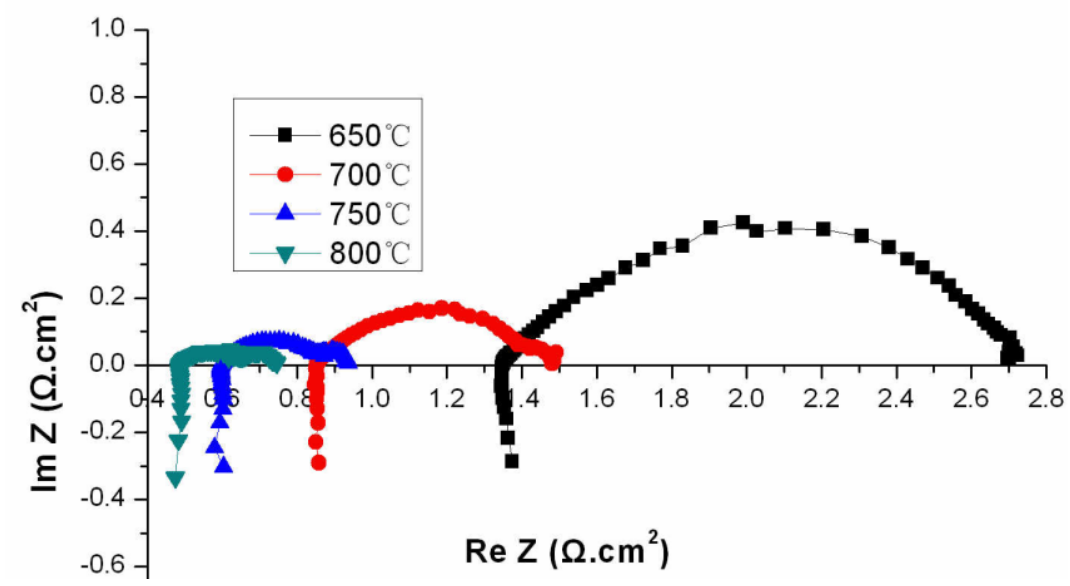

Figure 8. Impedance spectra of cells at different temperatures 
Figure 9 shows a typical current change as a function of time when the cell was operated at a constant voltage of $0.7 \mathrm{~V}$ with either $\mathrm{H}_{2}$ or $\mathrm{H}_{2}$ with $100 \mathrm{ppm} \mathrm{H}_{2} \mathrm{~S}$ as fuel gas in the anode while air as the oxidant in the cathode. Cell current decreased rapidly when 100ppm $\mathrm{H}_{2} \mathrm{~S}$ was introduced in the fuel gas stream, and the degradation rate slowed down with time and the cell performance was eventually stabilized. Upon removing $\mathrm{H}_{2} \mathrm{~S}$ from the fuel gas stream, the current started to improve rapidly with time, with cell performance partially recovered.

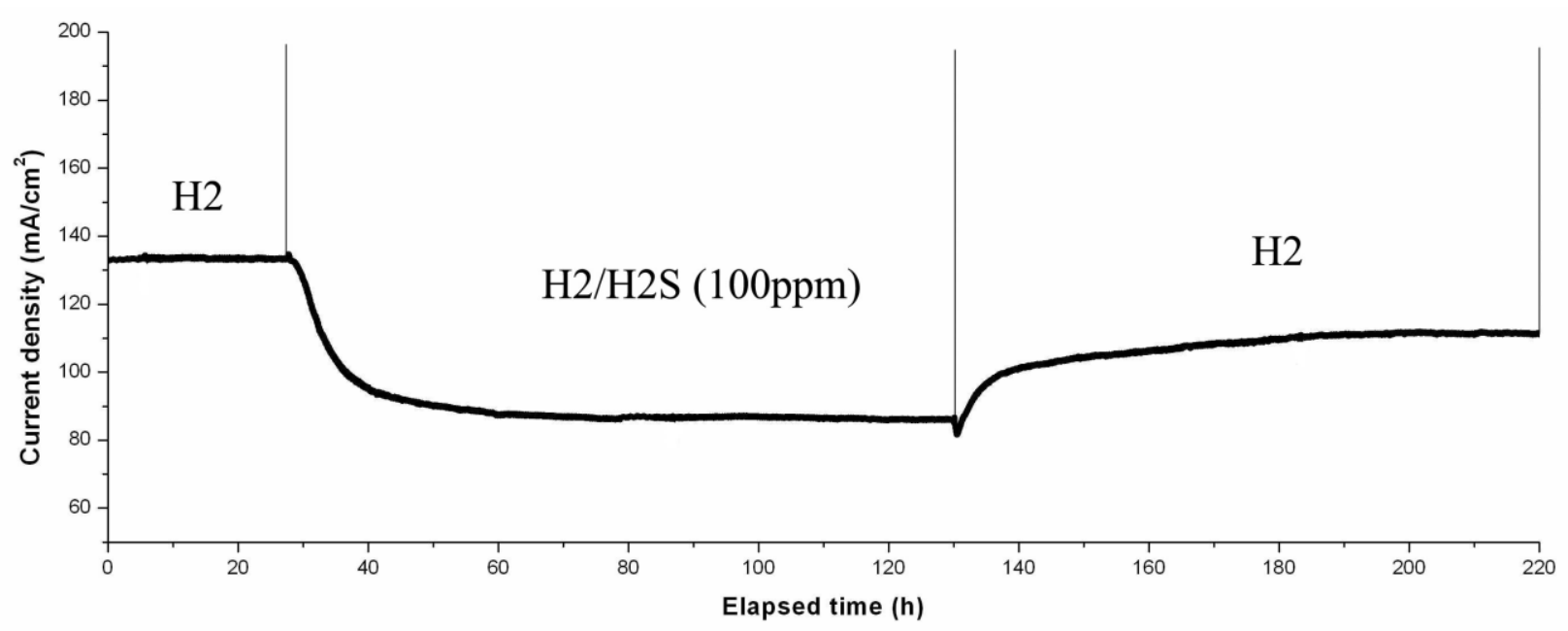

Figure 9. Long-term test of the cell with LSGMn anode in $\mathrm{H}_{2}$ and $\mathrm{H}_{2}$ with $100 \mathrm{ppm} \mathrm{H}_{2} \mathrm{~S}$

\section{Concluding remarks:}

The objective of this project is to develop a high performance solid oxide fuel cell (SOFC) which can directly operate on hydrocarbon fuels and achieve high power density. Over the course of the two-year project, this project goal has been achieved and the project accomplishments can be briefly highlighted below:

- Infiltration of $\mathrm{Ni}$ into ceria backbone has been shown to achieve cell performance stability with hydrocarbon fuels;

- Mixed ionic and electronic conducting electrode materials based on Sr- and Mn-doped $\mathrm{LaGaO}_{3}$ has been developed;

- Anode materials based on double provskite $\mathrm{Sr}_{2} \mathrm{Fe}_{1+\mathrm{x}} \mathrm{Mo}_{1-\mathrm{x}} \mathrm{O}_{6}$ which are capable of direct utilization of hydrocarbon fuels with tolerance to carbon formation and sulfur poisoning have been discovered;

- High power density SOFCs using hydrocarbon fuels (methane) have been demonstrated. 
Relevance: Develop materials for a high performance solid oxide fuel cells which can directly operate on hydrocarbon fuels and achieve high power density.

Approach: Prepared hierarchically porous electrode using self-rising technique and develop mixed conducting ceramic anode based on $\mathrm{LaGaO}_{3}$ system.

Technical Accomplishment and Progress: Hierarchically porous LSCF has been successfully prepared using self-rising technique; LSGM samples are prepared and shown promising conductivity in air.

Technology Transfer / Collaborations: One invention disclosure on self-rising approach has been filed. Collaborated with SRNL for nanostructured ceramic synthesis and AFRL for sulfur-tolerant ceramic anode work.

Proposed Future Research: Evaluated solid oxide fuel cell performance using hierarchically porous electrode and $\mathrm{LaGaO}_{3}$-based ceramic anode.

\section{Example Technical Publications}

1. Q. Liu and F. Chen, "Self-rising approach to synthesize porous hollow metal oxides", Journal of Nanoscience and Nanotechnology, 10 (2010) 4317-4321.

2. Q. Liu, X. Dong, C. Yang, S. Ma and F. Chen, "Self-rising synthesis of Ni-SDC cermets as anodes for SOFCs", Journal of Power Sources, 195 (2010) 1543-1550.

3. Q. Liu, and F. Chen, "Self-rising approach to synthesize hierarchically porous metal oxides", Materials Research Bulletin, 44 (2009) 2056-2061.

4. Q. Liu, F. Zhao, X. Dong, C. Yang, and F. Chen, "Synthesis and application of porous $\mathrm{S}_{\mathrm{m} 0.2} \mathrm{C}_{\mathrm{e} 0.801 .9}$ nanocrystal aggregates", Journal of Physical Chemistry C, 113 (2009) 1726217267.

5. F. Zhao, L. Zhang, Z. Jiang, C. Xia and F. Chen, "A high performance intermediate temperature solid oxide fuel cell using impregnated $\mathrm{La}_{0.6} \mathrm{Sr}_{0.4} \mathrm{CoO}_{3}$ cathode", Journal of Alloys and Compounds, 487 (2009) 781-785.

6. Z. Jiang, C. Xia, F. Zhao and F. Chen, "La ${ }_{0.85} \mathrm{Sr}_{0.15} \mathrm{MnO}_{3-\delta}$ infiltrated $\mathrm{Y}_{0.5} \mathrm{Bi}_{1.5} \mathrm{O}_{3}$ cathodes for intermediate-temperature solid oxide fuel cells", Electrochemical and Solid-State Letters, 12 (2009) B91-B93. 


\title{
Sub-Project3: Durability of Gaskets and Seals in PEM
}

\section{Fuel Cells}

\author{
Yuh J. Chao \\ Department of Mechanical Engineering \\ University of South Carolina
}

Objective: Develop a fundamental understanding how the degradation mechanisms of polymeric materials affects the performance and life of gasket/seals in PEMFC

\section{Relevance: Gasket/Seal as a structural member in Fuel Cells}

Interior

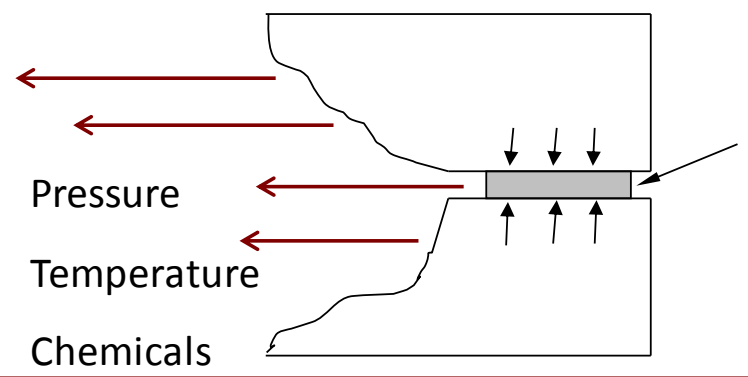

Ambient

Gasket or Seal

\section{Characteristics of gasket/seal :}

Under compression, exposed to chemicals, high temperature, pressure, cyclic conditions, etc.

Loss of functionality : by cracking and /or stress relaxation

Cracking: due to corrosion under compression (Chemical stability)

Stress Relaxation: material degradation... loss its sealing ability

(mechanical stability)

Leachants: detrimental sometimes (chemical stability) 


\section{Approach}

Task 1. Selection of Commercially Available Seal Materials (complete)

Task 2. Aging of Seal Materials (completed)

In simulated regular and accelerated FC environment (ADT)

With and without stress/deformation

Task 3. Characterization of Chemical Stability (completed)

FTIR, XPS, Weight loss, Atomic Absorption for leachants detection

Task 4. Characterization of Mechanical Stability (completed)

Tensile strength, ductility, DMA (Dynamic Mechanical Analyzer), microindentation, CSR (Compression Stress Relaxation)

Task 5. Development of Accelerated Life Testing Procedures (on-going)

Task 6. Industrial Interaction and Presentations (on-going)

Weight loss and chemical leaching (63 wks in ADT or Reg. at $80^{\circ} \mathrm{C}$ )
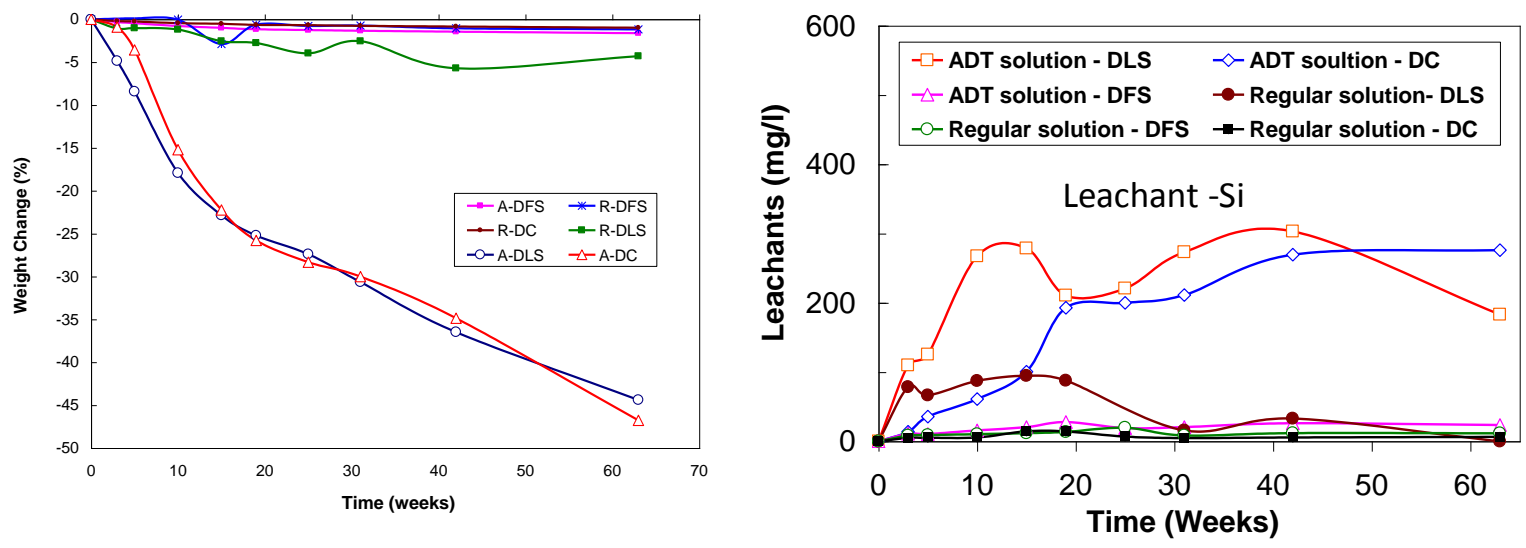
ATR-FTIR for DLS (ADT and Regular Solution)

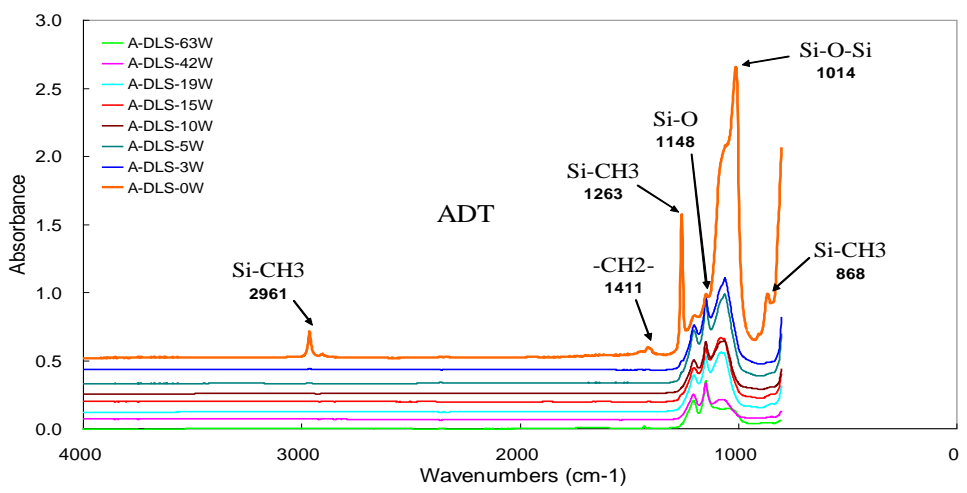

Chemical changes in backbone and crosslinked domain after 3 week exposure

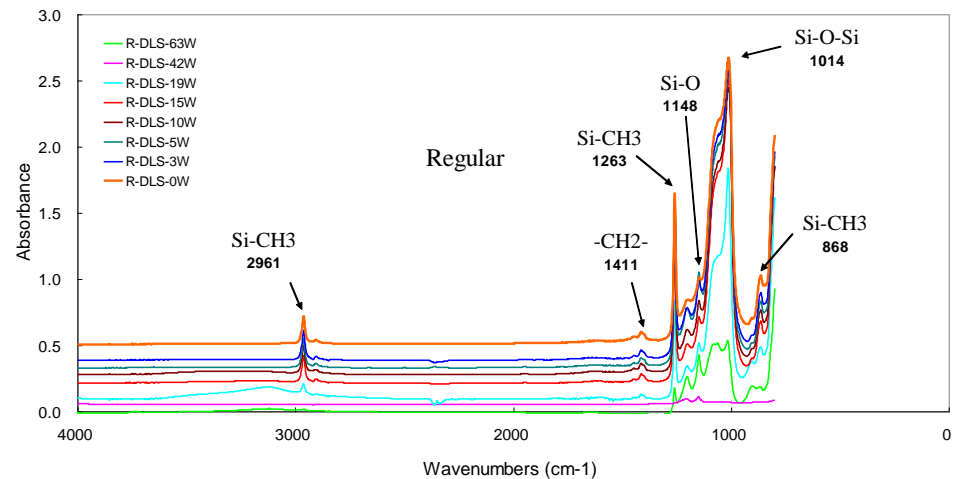

No significant Chemical Changes after 42 week exposure

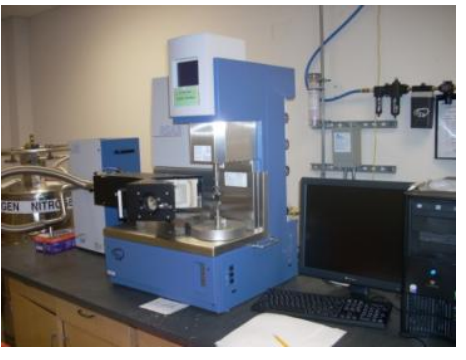

Dynamic Mechanical Analyzer (DMA) tests

- For polymers

- Temp scan from $70^{\circ} \mathrm{C}$ to $200^{\circ} \mathrm{C}$

- Tensile, bending and compression

- Elastic modulus, loss modulus

- Tg: glass transition temp

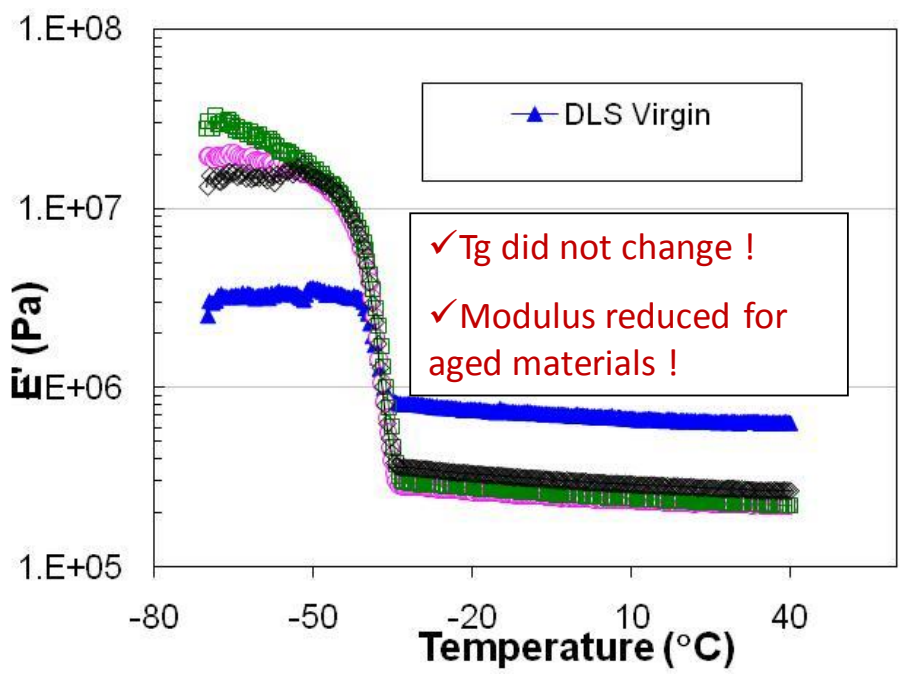


Stress relaxation and life prediction for polymeric gasket/seals in PEM fuel cell

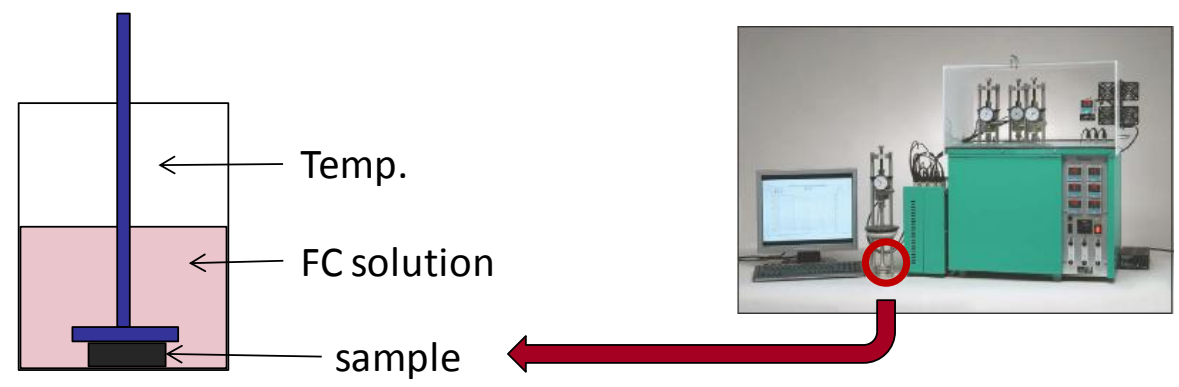

Life prediction using WLF time-temperature shift

\section{Life prediction under} actual PEMFC temp cycle
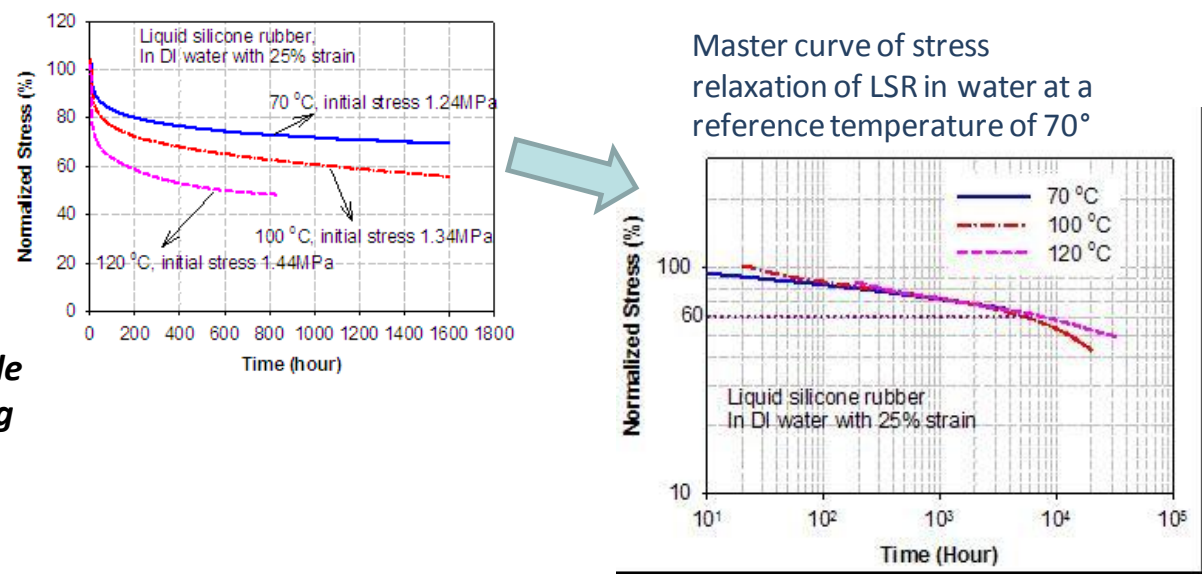
and humidity - on-going

$$
\text { Time (hour) }
$$

A comparison of storage modulus $\mathrm{E}^{\prime}$ of five seal materials (a)CR, (b)FSR, (c)LSR, (d)EPDM, and (e)FKM

Data reflect the glass transition temp. (i.e. temp at the sharpest drop) and stiffness of the materials at different temperatures

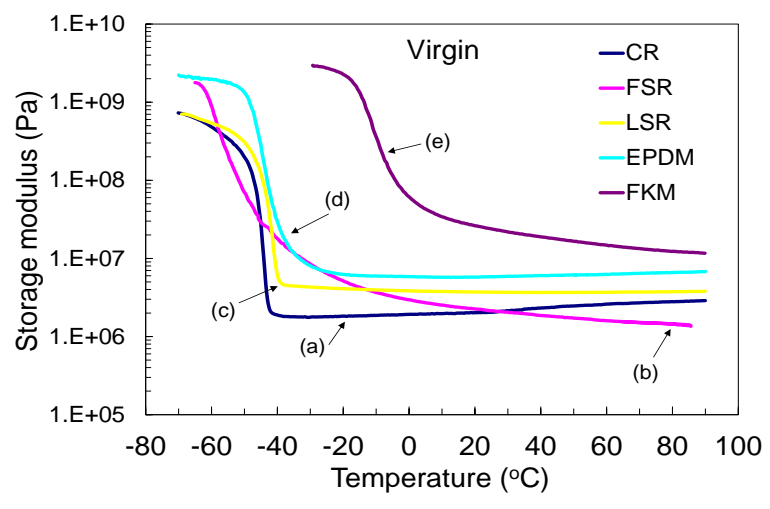

Seal pressure prediction predictive model development and verification

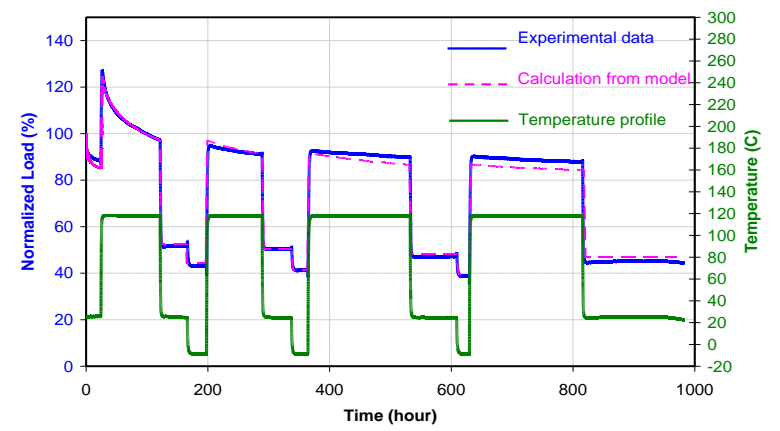

Comparison between experiment and prediction (LSR) 


\section{Sub-Project 3: Summary- Technical Accomplishment}

1. Optical microscope and SEM analysis to examine the degradation of surface.

2. ATR-FTIR test to elucidate the material surface chemical degradation.

3. Atomic adsorption spectrometry analysis to identify leachants from seals into the soaking solutions.

4. Microindentation test for assessing the mechanical properties of the gasket materials.

5. DMA for assessing the dynamical mechanical properties of the gasket materials.

6. Compression Stress relaxation test system to monitor the retained seal force under fuel cell condition

7. Developed life prediction methodologies using WLF concepts

8. On-going - model development and verification for predicting compressive stress retained in seals under realistic temperature cycles

9. Publications in Journal and Conferences and discussions with members in the USC NSF IUCRC Center for Fuel Cells

\section{Example Technical Publications - Seals/PEM}

Publications from Sub-project \#3 - seal/gasket durability in PEM fuel cells

1. Chih-Wei Lin, Chi-Hui Chien, Jinzhu Tan, Yuh-Jin Chao, and J.W. Van Zee, "Dynamic Mechanical Characteristics of Five Elastomeric Gasket Materials Aged in a Simulated and an Accelerated PEM Fuel Cell Environment," International Journal of Hydrogen Energy, to appear.

2. Cui, Tong, Lin, C-W., Chien, C.H., Chao, Y.J., Van Zee, J.W., " Service Life Estimation of Liquid Silicone Rubber Seals in Polymer Electrolyte Membrane Fuel Cell Environment," Journal of Power Source, 196 (2011) 1216-1221.

3. Chih-Wei Lin, Chi-Hui Chien, Jinzhu Tan, Yuh J. Chao, and J.W. Van Zee, "Chemical Degradation of Five Elastomeric Seal Materials in a Simulated and an Accelerated PEM Fuel Cell Environment," Journal of Power Source, 196(4), 2011, 1955-1966.

4. Tan, Jinzhu, Chao, Y. J., Yang, Min, Woo-Kum Lee, J. W. Van Zee, "Chemical and Mechanical Stability of a Silicone Gasket Material Exposed to PEM Fuel Cell Environment,” International Journal of Hydrogen Energy, 36 (2011) 1846-1852.

5. Tan, J., Chao, Y.J., Li, X., and Van Zee, J.W., "Microindentation test for Assessing the Mechanical Properties of Silicone Rubber Exposed to a Simulated PEM Fuel Cell Environment," ASME Journal of Fuel Cell Science and Technology, vol: 6 (4) 2009, 1550-1624.

6. Tan, J., Chao, Y.J., Wang, H., Gong, J., Van Zee, J.W., " Chemical and Mechanical Stability of EPDM in a PEM Fuel Cell Environment," Polymer Degradation and Stability, 94, 2009, 2072-2078.

7. Tan, J., Chao, Y.J., Van Zee, Li, X., Wang, X., and Yang, M., “Assessment of Mechanical Properties of Fluoroelastomer and EPDM in a Simulated PEM Fuel Cell Environment by Microindentation Tests," Materials Science and Engineering A, 496 (2008) 464-470.

8. Tan, J., Chao, Y.J., Yang, M., C.T. Williams, and Van Zee, J.W., "Degradation Characteristics of Elastomeric Gaskets Materials in a Simulated PEM Fuel Cell Environment," Journal of Materials Engineering and Performance, 17(6), 2008, 785-792. 


\title{
Sub-Project 4: Hydrogen Quality
}

\author{
John Van Zee \& Jean St. Pierre, Department of Chemical \\ Engineering
}

Objective: To quantify the mechanisms of performance and durability loss resulting from contaminants in the fuel for PEMFCs by performing experiments, analyzing data, and developing models. The study will provide equilibrium and rate constants suitable for use in new and existing models, and in computer code at Argonne National Laboratory.

\section{Objectives / Relevance}

Critical constituents for $\mathrm{H} 2$ quality are listed in Appendix $\mathrm{C}$ of the 2007 Technical Plan-Fuel Cells section of the Multi-Year Research, Development and Demonstration Plan. A North American Fuel Quality Team has been organized by Dr. James Ohi (NREL) to addresses the impact of these critical constituents as they affect the barriers of Durability, Cost, and Performance that are labeled A-C on page 3.4-25 of the Technical Plan. This project supports that team by obtaining experimental data, and is part of the cross-program effort on $\mathrm{H} 2$ quality that addresses parts of Tasks 1-3 and 8-10 of Table 3.4.15 entitled "Technical Task Descriptions" of the 2007 Technical Plan-Fuel Cells section of the Multi-Year Research, Development and Demonstration Plan. 


\section{Approach}

\begin{tabular}{|c|c|c|c|c|c|c|}
\hline \multirow{2}{*}{$\begin{array}{l}\text { Task } \\
\text { Number }\end{array}$} & \multirow[b]{2}{*}{ Project Milestones } & \multicolumn{4}{|c|}{ Task Completion Date } & \multirow[b]{2}{*}{ Progress Notes } \\
\hline & & $\begin{array}{l}\text { Original } \\
\text { Planned }\end{array}$ & $\begin{array}{l}\text { Revised } \\
\text { Planned }\end{array}$ & Actual & $\begin{array}{c}\text { Percent } \\
\text { Complete }\end{array}$ & \\
\hline 4.1 & $\begin{array}{l}\text { Develop techniques to } \\
\text { assess transport of } \mathrm{NH}_{3}\end{array}$ & 09/30/09 & & & $100 \%$ & complete \\
\hline 4.1 & $\begin{array}{c}\text { Develop techniques to } \\
\text { assess transport of Sulfur } \\
\text { species; }\end{array}$ & 09/30/09 & & & $00 \%$ & complete \\
\hline 4.1 & $\begin{array}{c}\text { Measure transport rates } \\
\text { and assess effect on } \\
\text { contamination }\end{array}$ & $03 / 30 / 10$ & & & $100 \%$ & complete \\
\hline 4.1 & $\begin{array}{l}\text { Develop improved } \\
\text { activation-loss model }\end{array}$ & $10 / 30 / 09$ & & & $100 \%$ & On-Track \\
\hline 4.2 & $\begin{array}{l}\text { Develop techniques to } \\
\text { measure the isotherms } \\
\text { and rate constants of } \\
\text { Sulfur species }\end{array}$ & $06 / 30 / 10$ & & & $100 \%$ & complete \\
\hline 4.2 & $\begin{array}{c}\text { Develop techniques to } \\
\text { measure ion exchange } \\
\text { and reaction rates of } \mathrm{NH}_{3}\end{array}$ & $08 / / 30 / 10$ & & & $100 \%$ & complete \\
\hline 4.3 & $\begin{array}{c}\text { Publish comparison of } \\
\text { model with performance } \\
\text { data }\end{array}$ & $06 / 30 / 10$ & & & $100 \%$ & On-Track. \\
\hline 4.3 & $\begin{array}{c}\text { Disseminate the data and } \\
\text { findings }\end{array}$ & $10 / 31 / 10$ & & & $100 \%$ & Ongoing. \\
\hline
\end{tabular}

We have shown that the $\mathrm{NH}_{3}$ fuel contamination mechanism is one of ion-exchange and that specification of the fuel quality concentration depends on dosage and capacity of the MEA.

Amount of $\mathrm{NH}_{3}$ detected from both electrodes by the effect of anode humidity with $100 \mathrm{ppm} \mathrm{NH} / \mathrm{N}_{2}$ (Flow rate $\mathrm{A} / \mathrm{C}=150 \mathrm{sccm}$, Temp.: A/C/Cell $\left.=78 / 73 / 70^{\circ} \mathrm{C}\right)$

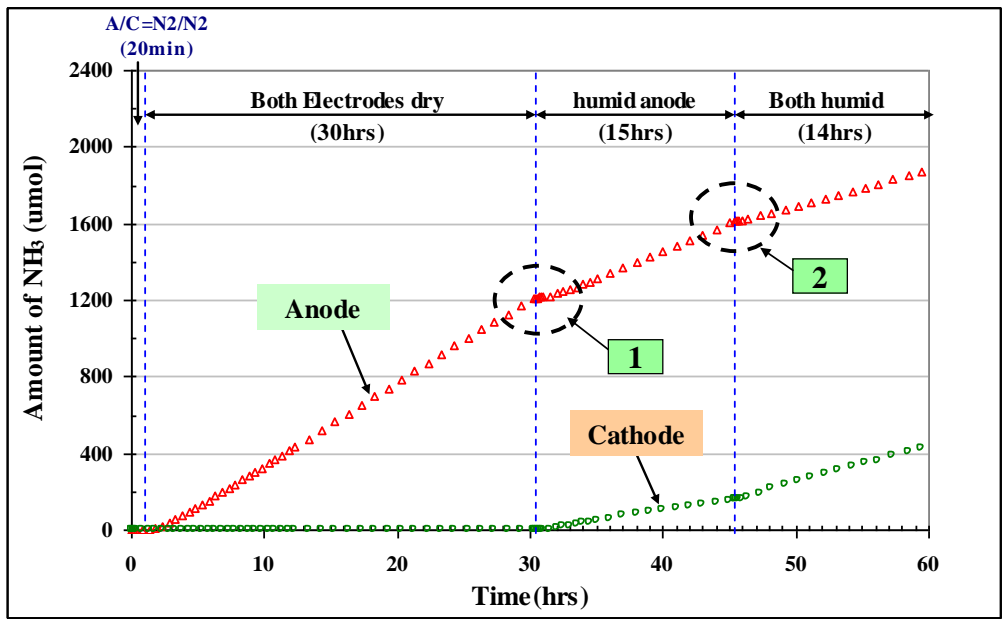

We can explain these results by considering that under humid conditions $\mathrm{NH}_{3}$ would be dissolved in water and converted to $\mathrm{NH}_{4}+$ which could displace (by ion exchange?) an $\mathrm{H}+$ in the ionomer of the electrode and/or the membrane. 
We have developed material balance techniques which allow for measurement of the flux and concentration during operation. We couple this material balance technique with reference electrode techniques.

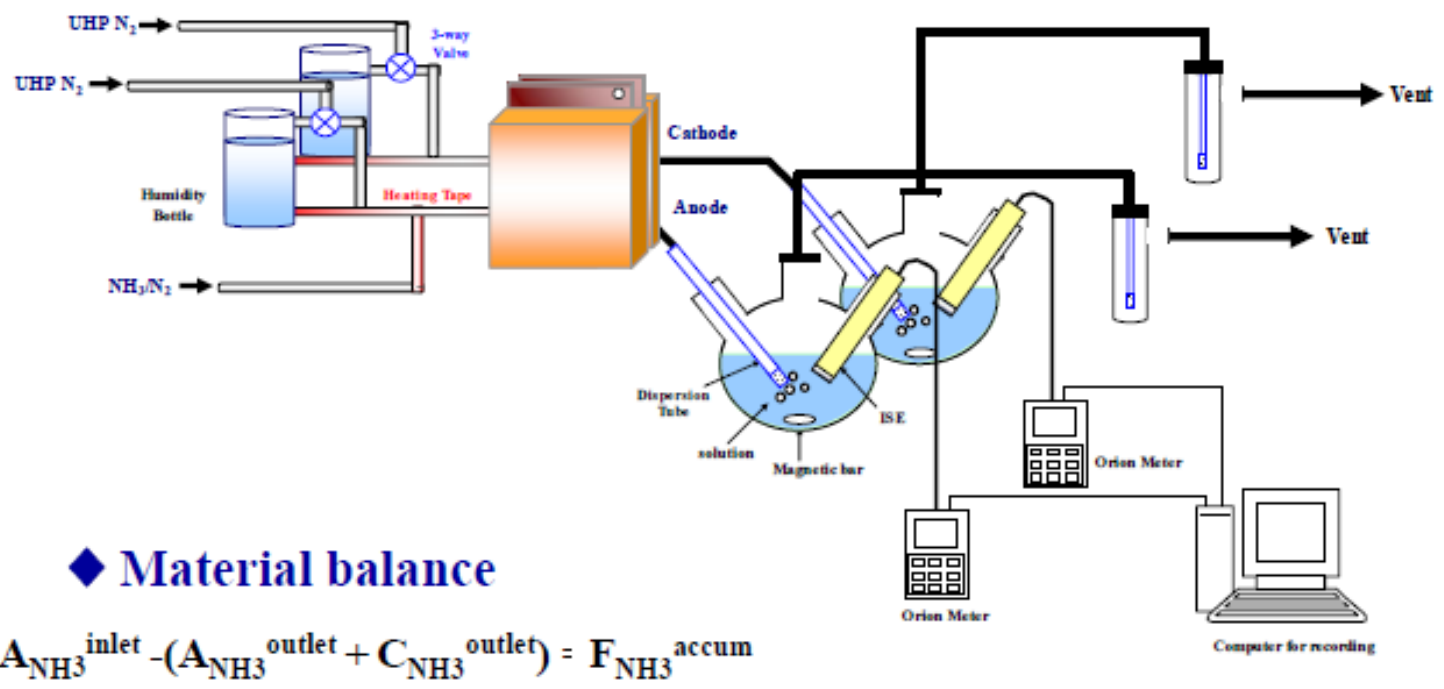

$\mathbf{A}_{\mathrm{NH} 3}, \mathrm{C}_{\mathrm{NH} 3}, \mathbf{F}_{\mathrm{NH} 3}$ in moles

We have developed reference electrode techniques to measure the change in electrode reactions during the transport of $\mathrm{NH}_{3}$ from the anode to the cathode during open circuit conditions
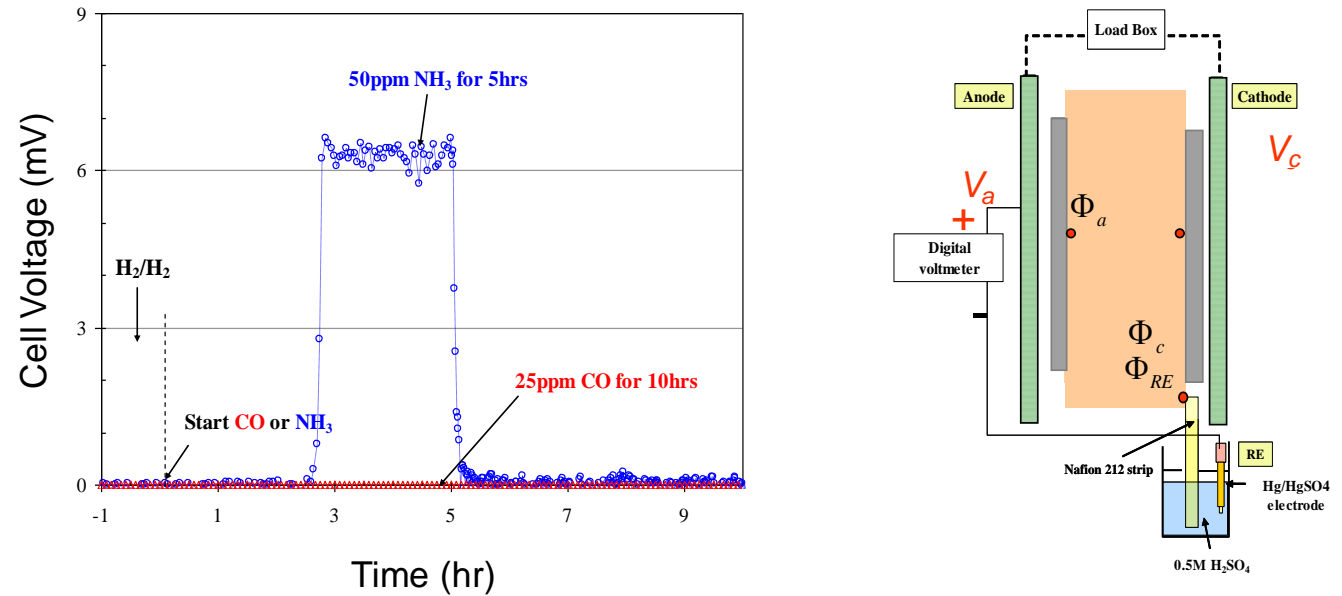

Here we show that 25 ppm CO does not affect the open circuit voltage but that 50 ppm $\mathrm{NH}_{3}$ changes the cell voltage at open circuit after the MEA is fully exchanged. The $6 \mathrm{mV}$ change corresponds to the $\mathrm{NH}_{3}$ partial pressure $\mathrm{s}$. 
Here we show that $25 \mathrm{ppm} \mathrm{CO}$ does not affect the anode overpotential at open circuit voltage but that $50 \mathrm{ppm} \mathrm{NH}_{3}$ changes the measured reference voltage at open circuit after the MEA is fully exchanged. The $310 \mathrm{mV}$ change corresponds to the $2 \mathrm{NH}_{3}+\mathrm{H}_{2}=2 \mathrm{NH}_{4}^{+}+2 \mathrm{e}-$ at these partial pressures.
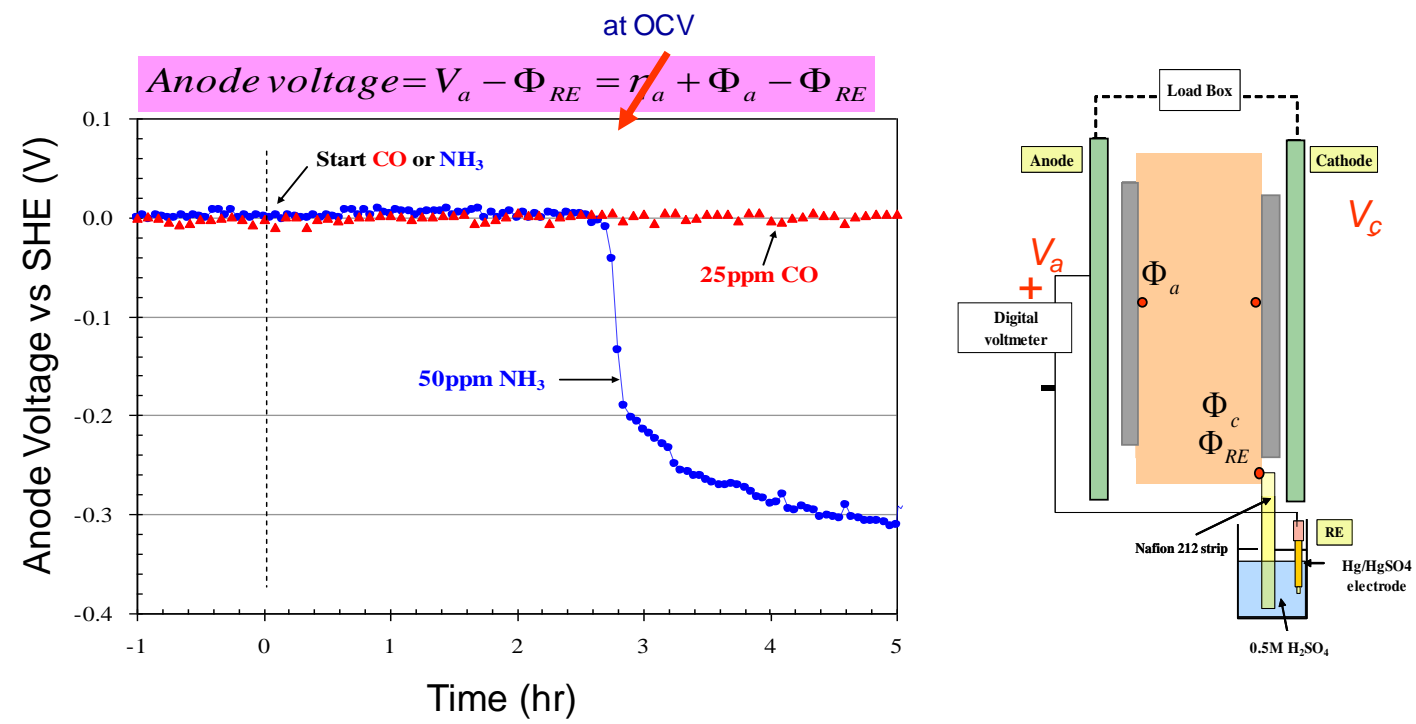

We have shown that the transport and breakthrough is a local process because the MEA is thin compared to the channel length. Here we positioned the reference electrode at two positions. Case A corresponds to the exit and Case B is close to the entrance. This indicates that transport occurrs after complete local exhange of the MEA.

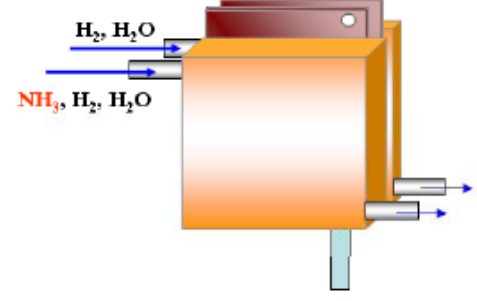

$<$ Case $\mathrm{A}>$ : $\mathrm{NH}_{3}$ flow from top to bottom

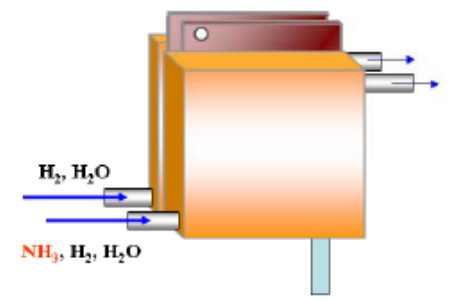

$<$ Case $\mathrm{B}>$ : $\mathrm{NH}_{3}$ flow from bottom to top

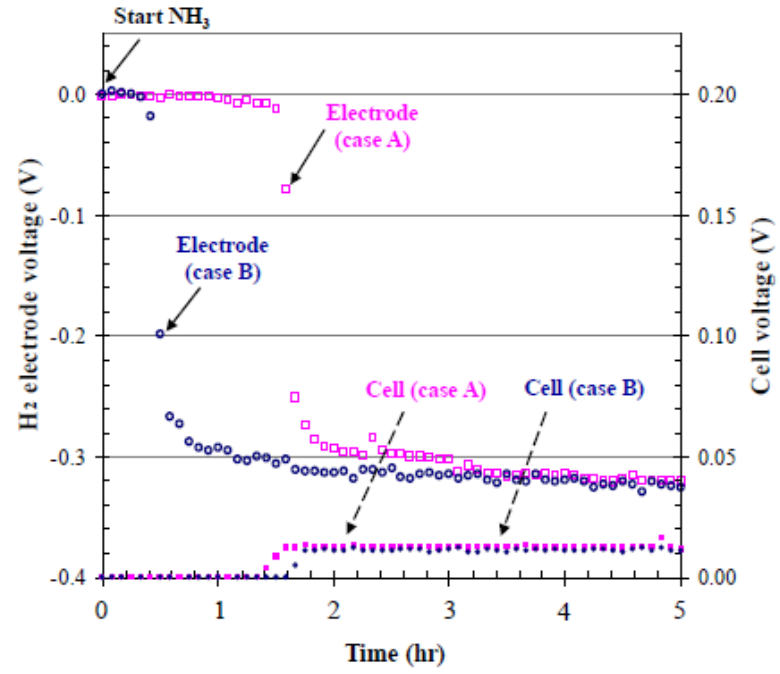


We have shown that the transport is enhanced by migration in our hydrogen pump experiments. Below., with no current, there is a partition of the $\mathrm{NH}_{3}$ exiting the cell which again corresponds to the partial pressure for the $\mathrm{H}_{2}+\mathrm{NH}_{3}$ reaction. Reversal of the voltage changes the exit concentrations.

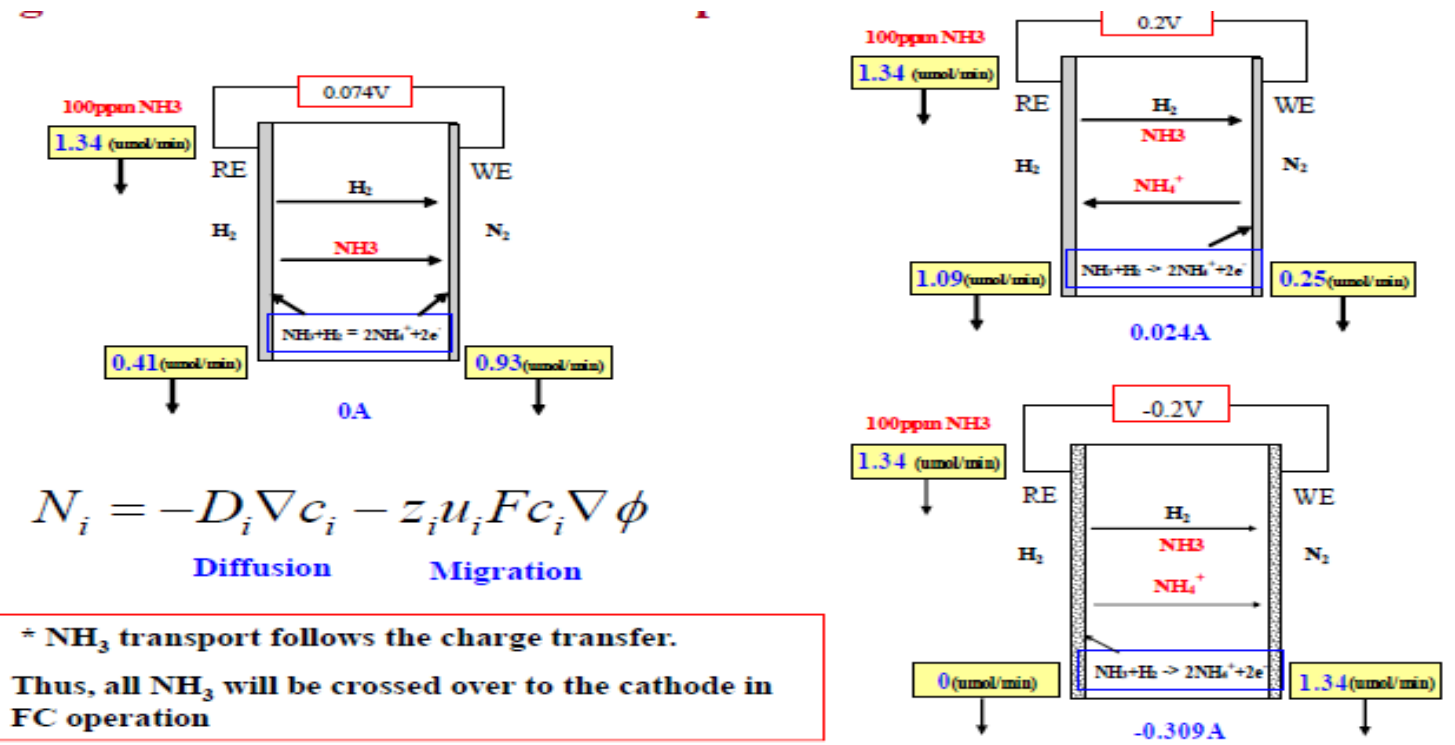

FC operation

\section{Accomplishments / milestones:}

We have developed temperature programmed desorption techniques to identify the sulfur species that adsorb on the cathode through temperature programmed desorption and reaction. We chose $\mathrm{SO}_{2}$ as a preliminary model compound for sulfur species in the fuel that may be transported to the cathode. It also serves the purpose as an air contaminant. The strongly adsorbed species may accumulate so that dosage is a important variable.
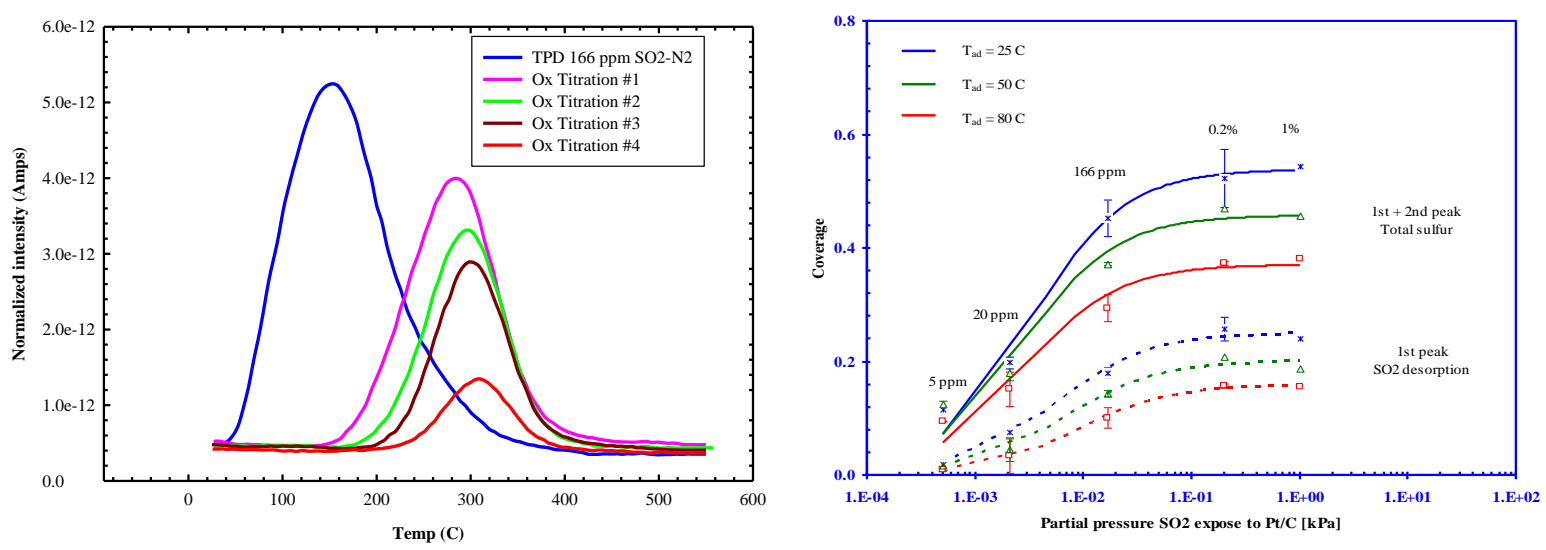
When we separate the effect of $\mathrm{O}_{2}$ from $\mathrm{N}_{2}$ we observe a "spillover" effect that is facilitated by Pt. This spillover gives an apparent isotherm which exceeds the Pt sites. We found that this effect is not reversible because the $\mathrm{C}-\mathrm{SO}_{2}$ is strong enough that once the $\mathrm{SO}_{2}$ is removed from the Pt, the Pt sites are not re-contaminated.
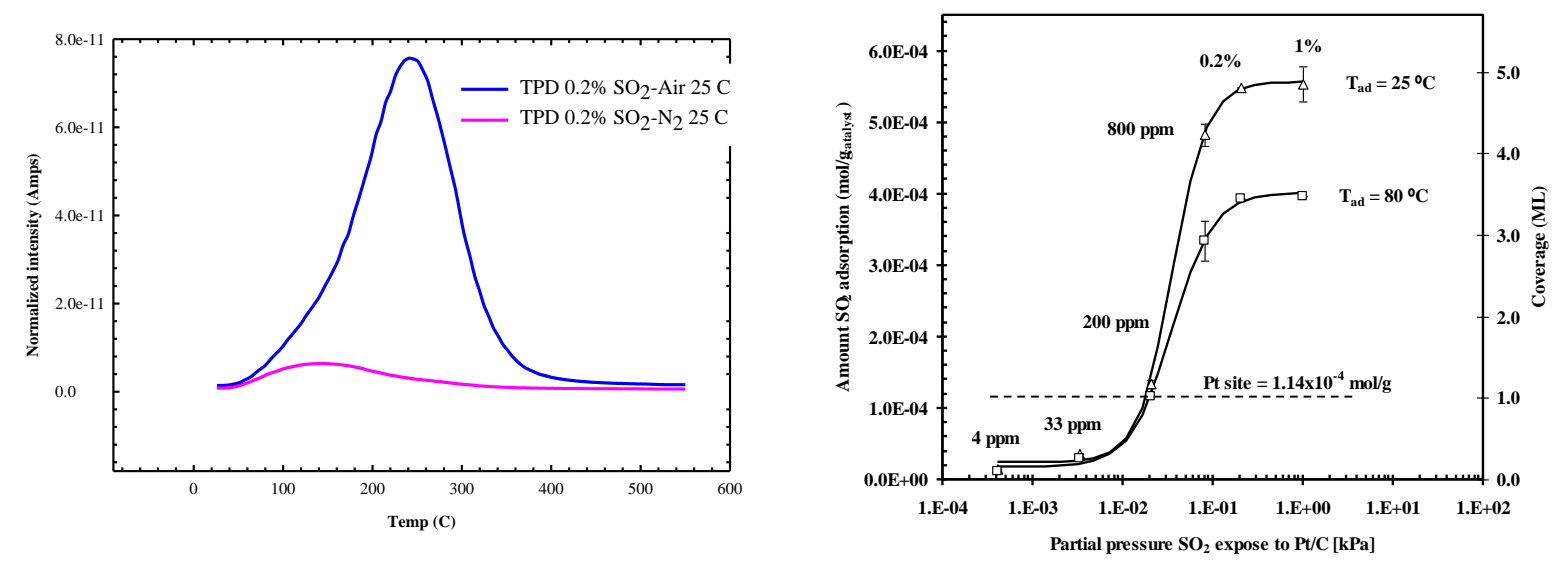

\section{Accomplishments / milestones:}

A model was developed for the case of a contaminant that leads to a catalyst surface adsorbate that does not desorb. Two catalyst sites are required to reproduce the main experimental observation (partial performance recovery). The model appears valid with simple inorganic sulfur based contaminants $\left(\mathrm{H}_{2} \mathrm{~S}, \mathrm{SO}_{2}, \mathrm{COS}\right)$
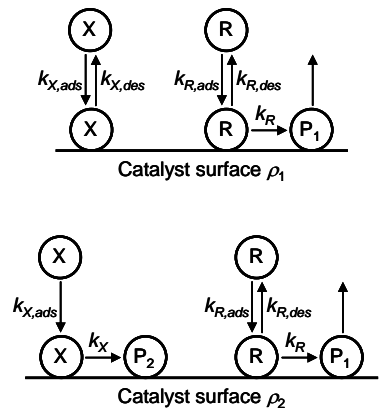
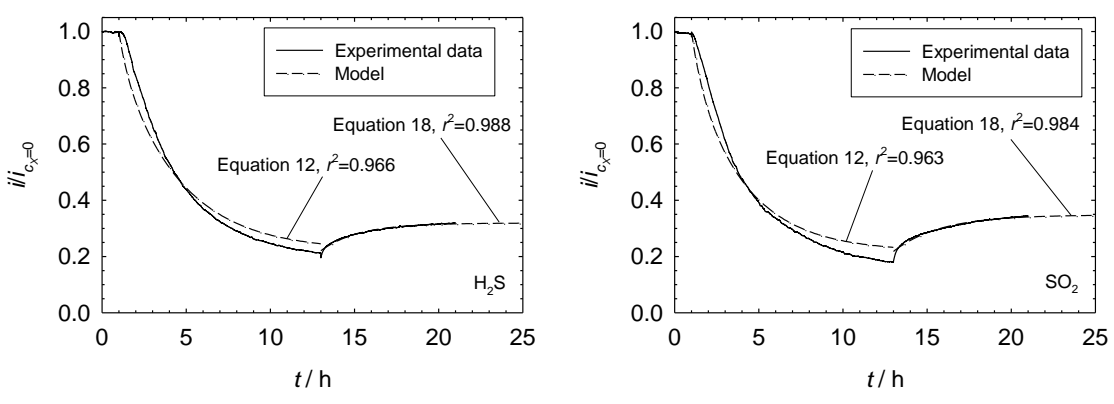


\section{Technical Accomplishments \& Progress $-\mathrm{H}_{2}$ Quality Accomplishments / milestones:}

A method to extract kinetic rate constants is proposed and consists in the sequential measurement of current changes in the presence of a reactant, a contaminant and their combination. Use of model current change expressions (initial and steady state values, linear regime slopes) with corresponding experimental data is sufficient to determine all rate constants required for predictions. Comparison between model predictions and experimental data with both reactant and contaminant provides a steric effect diagnosis.

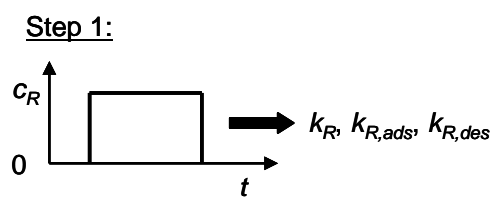

Step 2:
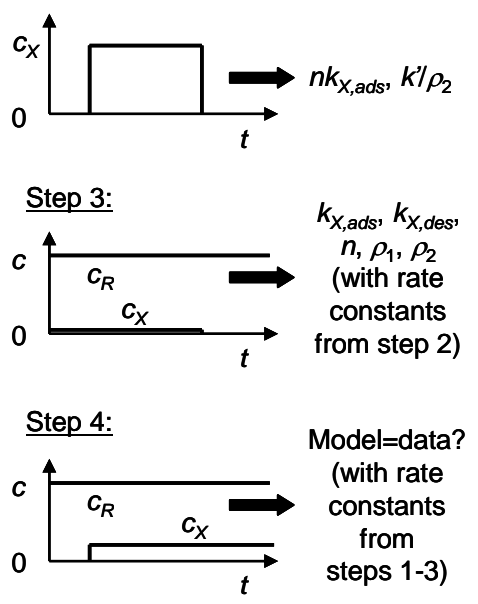

In the absence of recovery (liquid water, potential changes, etc), the model is able to predict a sulfur contaminant tolerance limit (worse case scenario) because rate constants and steady state current values are either independent or directly proportional to contaminant concentration. Because the steady state current loss is always at least equal to $1-\rho_{1} / \rho$, the contaminant concentration is set to less than $0.7 \mathrm{ppb}$ ensuring the dominant rate constant is larger than the application life of $5000 \mathrm{~h}$.

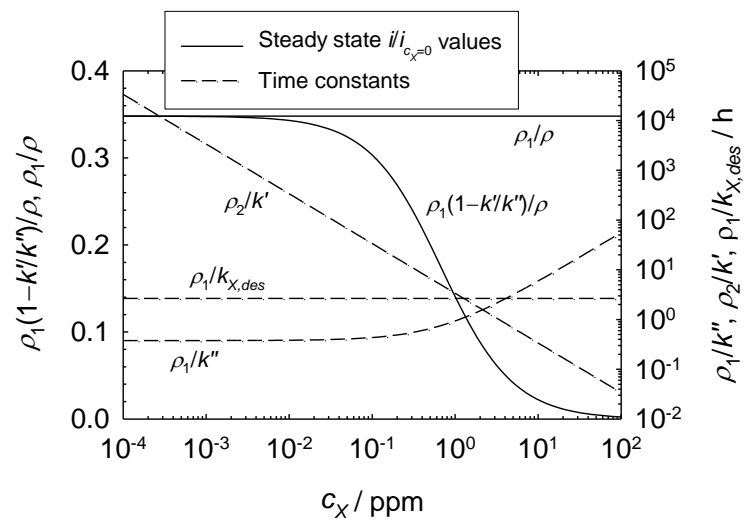


The model predicts a significant effect of catalyst loading. Performance loss due to contamination is dependent on total catalyst site density $\rho$ and individual site densities $\rho_{1}$ and $\rho_{2}$. A catalyst loading reduction significantly impacts the steady state current loss $1-\rho_{1} / \rho$. Validation data obtained with a $0.4 \mathrm{mg} \mathrm{Pt} / \mathrm{cm}^{2}$ leads to a 0.65 loss whereas a catalyst loading decrease to 0.1 $\mathrm{mg} \mathrm{Pt} / \mathrm{cm}^{2}$ leads to a 0.91 loss corresponding to a $40 \%$ increase.

Contamination

$$
\frac{i}{i_{c_{X}=0}}=\frac{1}{\rho}\left[\rho_{1}\left(1-\frac{k^{\prime}}{k^{\prime \prime}}\left(1-e^{\frac{-k^{\prime \prime} t}{\rho_{1}}}\right)\right)+\rho_{2} e^{\frac{-k^{\prime} t}{\rho_{2}}}\right] \quad \frac{i}{i_{c_{X}=0}}=\frac{\rho_{1}}{\rho}\left(1-\theta_{X, 0} e^{\frac{-k_{X, d e s} t}{\rho_{1}}}\right)
$$

The present model increases the existing inventory of cases derived using similar assumptions. In presence of a reactant, models generally show a similar behavior. In absence of a reactant, reaction mechanism identification is facilitated because different current transients occur with only a contaminant in the reactant stream.

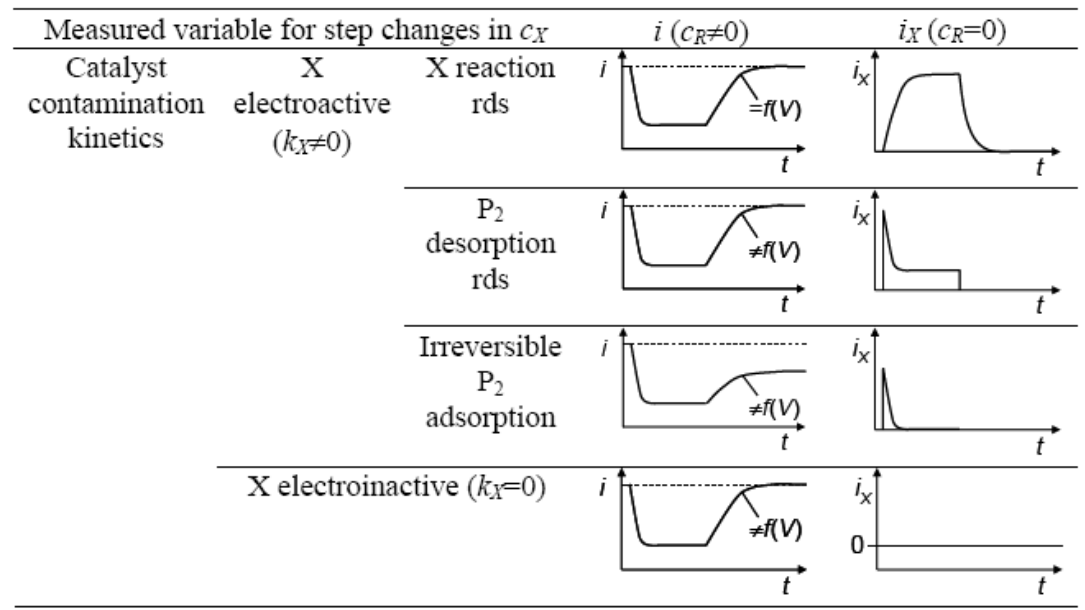


A method to extract rates constants for the case of a contaminant that desorbs from the catalyst surface was proved and the limitations were illustrated. For instance, the figure shows the current resulting from a pulse of hydrogen. Different electrode potentials and hydrogen concentrations were investigated. Subsequently, mixtures of hydrogen and carbon monoxide were investigated.

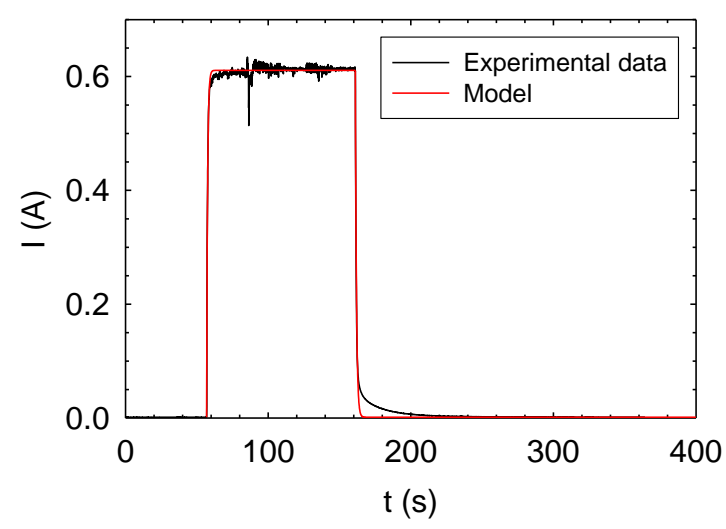

Example Publications:

1. Tan, J., Chao, Y.J., Wang, H., Van Zee, J.W., "Chemical and mechanical stability of EPDM in a PEM fuel cell environment," accepted for publication in Polymer Degradation and Stability, July 2009.

2. T. T. Nwoga and J. W. Van Zee, "Estimated Rate Constants . for CO Poisoning of High Performance Pt/Ru-C Anodes," Electrochemical and Solid State Letters, 11, B122 (2008) 


\section{Sub-Project 4: Summary- Technical Accomplishments}

- The extent of transport of $\mathrm{NH}_{3}$ has been quantified as a function of humidity in the anode and cathode streams; a mechanism for the transport and contamination has been verified at open circuit conditions to serve as a baseline for studying transport and reaction under load.

- Ex-situ methods have been developed to measure and identify sulfur species that remain on the catalysts and to measure isotherms for $\mathrm{SO}_{2}$ adsorption on $\mathrm{Pt} / \mathrm{C}$ catalysts using temperature programmed desorption/reaction techniques. At least two sulfur species on the surface of Pt catalysts in the presence of $\mathrm{N}_{2}$ are indicated. Studies in the presence of $\mathrm{O}_{2}$ and $\mathrm{H}_{2} \mathrm{O}$ have been started. These studies have implications for sulfur species transport from fuel contaminants.

- A new model that describe partial recovery of performance indicative of simple sulfur based inorganic contaminants was completed. A procedure was proposed to determine all model rate constants. The model was used to predict a tolerance limit (worse case scenario) and the effect of a catalyst loading reduction.

- Rate constants were extracted from experimental data for the case of a contaminant that desorbs from the catalyst surface. More specifically, establishing correlations between experimental data and model allowed predictions of the effect of contaminant concentration and electrode potential. 


\section{Sub-Project 5: Multi-physics Materials System Foundations for Durability Modeling in Solid Oxide Fuel Cells and Electrolyzers}

Chris Xue and Ken Reifsnider, Department of Mechanical Engineering

Objective: To build a first principles multiphysics durability model based on interpretations of Electrochemical Impedance Spectroscopy (EIS) data that link the multiphysics processes, the microstructure, and the material states (and their changes), with cell impedance responses and global performance mechanistically.

\section{Specific focus}

- Material synthesis for intermediate temperature(IT)SOFC systems

- Solid state and chemical methods for material synthesis

- X-Ray diffraction to examine material phases

- SEM to examine microstructure

- Electrochemical characterization

- V-I curves

- Electrochemical impedance spectroscopy

- Durability

- Mechanistic EIS model and mechanism study

- CFD based multi-physics model for SOFCs and electrolyzers

- Mechanistic EIS simulation

- Mechanistic EIS model based experimental data interpretation 


\section{Cathode and electrolyte material synthesis for IT-SOFC development}

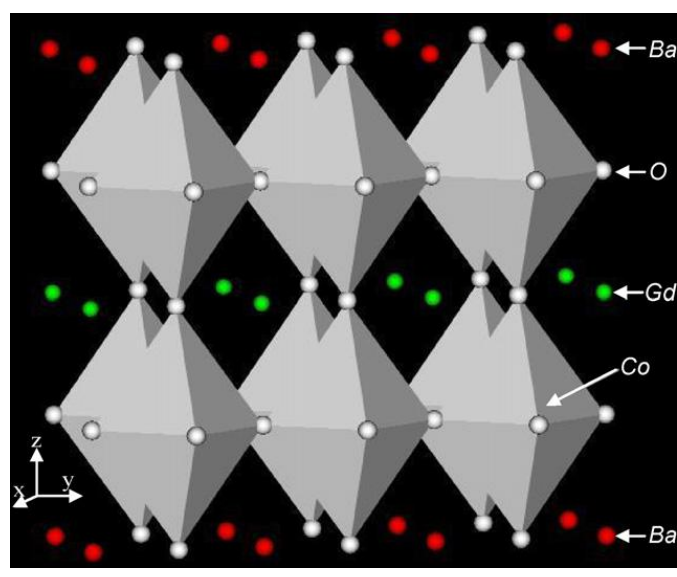

Crystal structure of layered perovskite

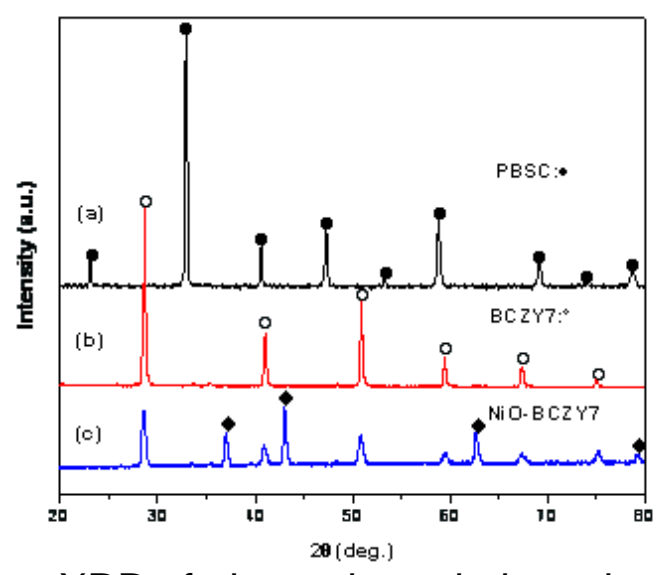

XRD of electrode and electrolyte

- A series of new layered perovskite cathode materials are synthesized for IT-SOFCs

- Both proton conducting and ion conducting electrolyte materials are synthesized

- H. Ding and X. Xue, "GdBa0.5Sr0.5Co2O $5+\delta$ layered perovskite as promising cathode for proton conducting solid oxide fuel cells," Journal of Alloys and Compounds, 2010, (in press)

- H. Ding and X. Xue, "A novel cobalt-free layered $\mathrm{GdBaFe} 2 \mathrm{O} 5+\delta$ cathode for proton conducting solid oxide fuel cells," Journal of Power Sources, Vol. 195, 2010, pp. 4139. 


\section{Electrochemical characterization of IT-SOFC material systems}

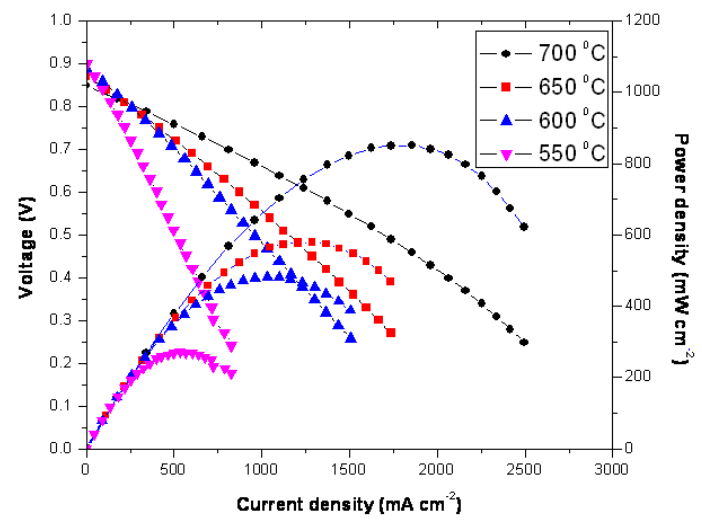

$\mathrm{PrBaSrCo/SDC/SDC-NiO} \mathrm{performance}$

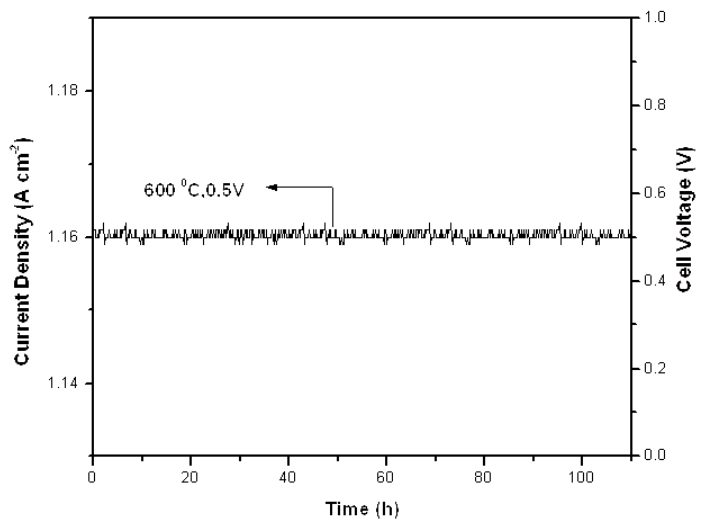

Durability test

- Cell performance is very promising in intermediate temperature conditions

- Durability tests demonstrated that SOFC performance is quite stable

- H. Ding and X. Xue, "PrBa0.5Sr0.5Co2O5+סlayered perovskite cathode for intermediate temperature solid oxide fuel cells," Electrochimica Acta, Vol. 55, 2010, pp. 3812.

\section{EIS characterization of IT-SOFC material systems}

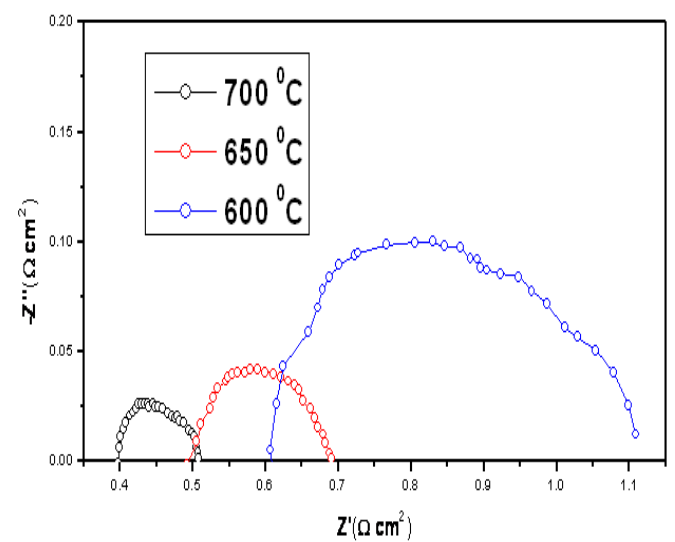

EIS of $\mathrm{NiO}-\mathrm{SDC} / \mathrm{SDC} / \mathrm{SBSC}$

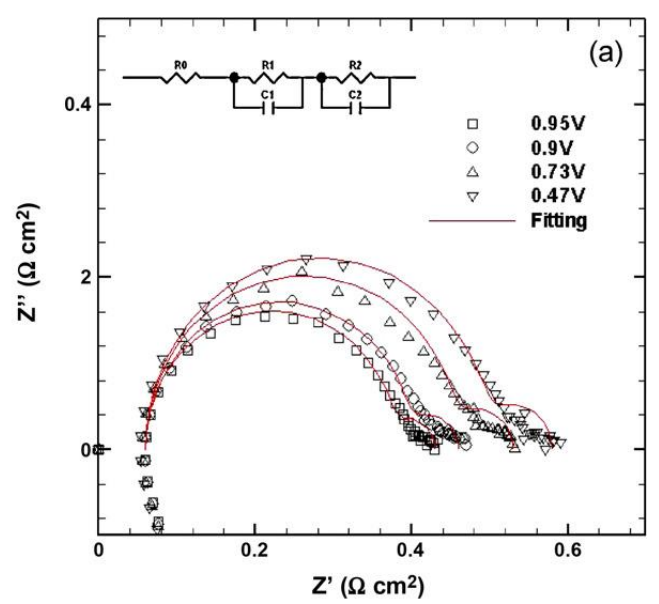

EIS evolution under different loadings

- Electrochemical impedance spectroscopy has been measured for SOFCs under different operating conditions;

- Fundamental mechanisms study using model based data interpretation 


\section{SOFC model and EIS simulation}

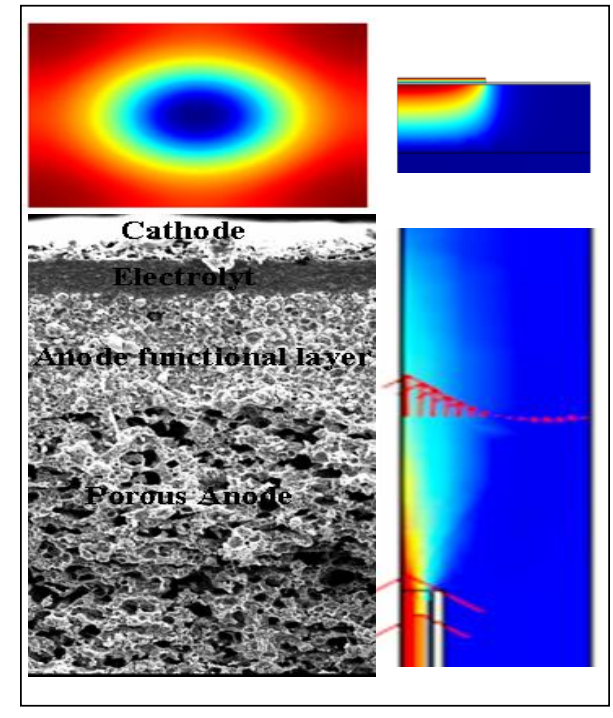

CFD based multi-physics model
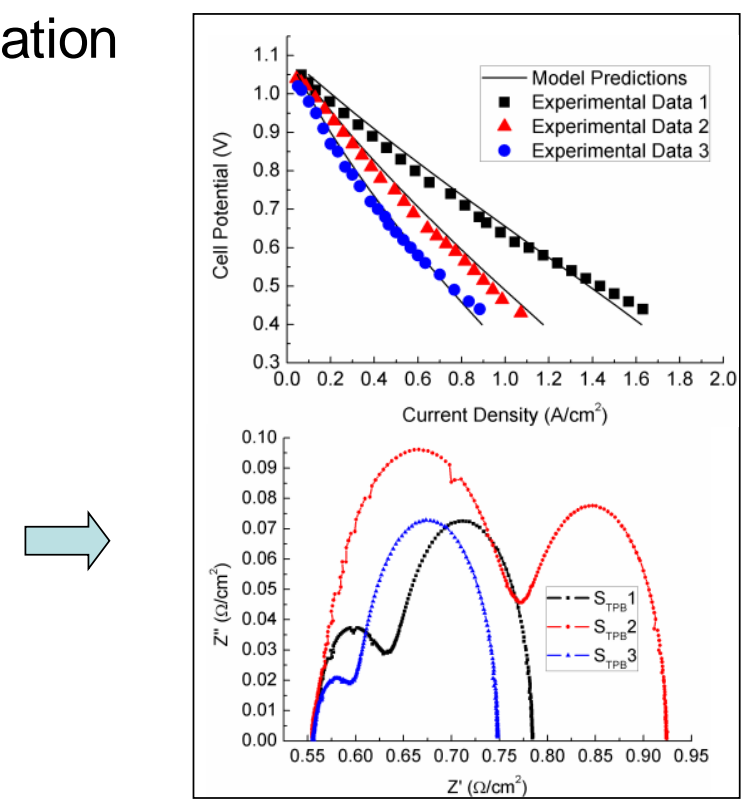

Simulations of polarization performance and EIS

- Linked the distributed transport and electrochemical reaction processes, material state and microstructure to SOFC polarization performance

- Successfully built mechanistic EIS simulation approach

- A few journal papers are under review 


\section{Technical accomplishments - milestones}

1. A series of cathode and electrolyte materials have been successfully synthesized and characterized;

2. A series of SOFCs have been fabricated and tested;

3. Extensive electrochemical characterizations have been performed, including V-I curves, impedance spectroscopy, durability test;

4. CFD based multi-physics SOFC/SOEC models have been developed;

5. Multi-physics model based mechanistic EIS simulation approach has been established for experimental data interpretation;

6. Publications: so far 18 journal papers, one book chapter, and 4 conference papers have been published from this funding support;

7. Presentation and poster: research results have been presented in various conferences, such as fuel cell seminar and exposition, American ceramic society, ASME fuel cell science and technology, etc.;

8. Instrument purchased: Solartron 1260 frequency response analyzer, Solartron 1287 potentiostat for EIS measurement. 


\section{Technical accomplishments - Example Publications}

\section{Book Chapter}

1. J.Shiand X.Xue, (2010) "3D CFD Analysis for Solid Oxide Fuel Cells with Functionally Graded Electrodes," in Advancesin Solid Oxide Fuel Cells VI: Ceramic Engineering and Science Proceedings, Volume31, John Wiley \&Sons, Inc., Hoboken, NJ, USA. doi:10.100219780470943984.ch14

\section{Journal papers}

1. Ding, H.:Xie, Y.; Xue, X., "Electrochemical performance of BaZrro.1Ce0.7Y0.1Yb0.103-Delectrolytebased proton-conducting SOFC with lavered perovskite PrBaCo205+סcathode", Journalof Power Sources, Volume 196, Issue 5, pp. 2602-2607,(2011).

2. Shi,J.;Xue, X., "Bi.functionally Graded Electrode Supported SOFC Modeling and Computational Thermal Fluid Analysis for Experimental Design", ASMEJournalof FuelCell Scienceand Technology, Vol.8, 2011, 011005-1-10.

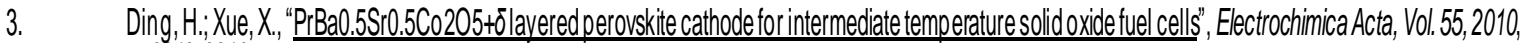
pp3812-3816.

4. Shi, J:, Xue, X., "CFD analysis ofanovel symmetrical planar SOFC design with micro-tlowchannels", Chemical Engineering Journal, Vol. 163, 2010, pp 119-125.

5. Ding, H:; Xue, X., "A novel coballiffreelayered GdBaFe205+ocathodeforproton conducting solid oxidefuel cells", Journal of Power Sources, Vol. 195, 2010, pp 4139-4142.

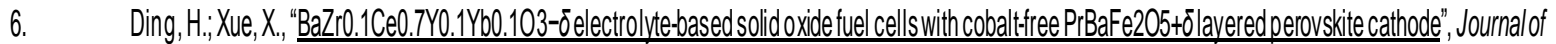
Power Sources, Vol. 195, 2010, pp 7038-7041.

7. Shi, J.; Xue, X., "CFD analysis of asymmetrical planar SOFCwith heterogeneouselectrodeproperties", ElectrochimicaActa, Vol.55, 2010, pp 5263-5273.

8. Ding, H.:Xue, X:; Liu, X:; Meng, G. "Hiah perfomance protonicceramic membranefuel cells (PCMFCS) with Sm0.5Sr0.5Co03-0perovskite cathode," Journalof Alloys and Compounds, Volume 494, 2010, 233.

9. Ding, H., Xue, "Coball-freelayered perovskite GdBaFe205+oas a novel cathode for intermediatetemperature solidoxidef fuel cells", Journal of Power Sources, Vol. 195,2010, pp 4718.

10. Ding, H:; Xue,X:" Liu,X:; Meng, G., "Anovel layered perovskite cathode for proton conducting solid oxidefuel cells,"Journal of Power Sources, Volume 195, 2010, 775 .

11. Jin, X. and Xue, X., "Computational fluid dynamics analysis of solid oxide electrolysis cells swith delaminations," International Journal of Hydrogen Energy, Volume 35, Issue 14, July 2010, Pages 7321-7328.

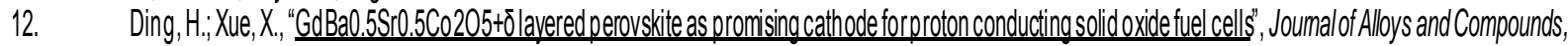
Vol. 496, 2010, pp 683-686.

13. Jin, X. and Xue, X," "Mathematical Modeling Analysis of Regenerative Solid Oxide Fuel Cells in Switching Mode Conditions", Journal of Power Sources, Volume 195, Issue 19, 1 October 2010, Pages 6652-6658.

14. Ding, H. and Xue, X., "Lavered perovskite GdBaCOFe05+xas cathodefor intermediate-temperature solid oxidefuel cells," International IJournal of Hydrogen Energy, Volume 35, Issue9, May 2010, Pages 4316-4319.

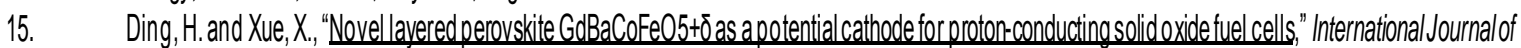
Hydrogen Energy, Volume 35, Issue9, May 2010, Pages 4311-4315.

16. Ding, H. and Xue, X. "Proton conducting solid oxide fuel cellswith lavered PrBa0.5Sr0.5C0205+5perovskitecathode," International Journal of Hydrogen Energy, Volume 35, Issue 6, March 2010, Pages 2486-2490.

17. Y.Xie and Xue, X "Transientmodelingofanode-supported solid oxidefuel cells," International Journalof Hydrogen Energy, Volume 34, Issue 16, August2009, Pages 6882-6891.

18. Ding, H.: Xue, X: Liu, X:; Meng, G. "Hiah performancelavered SmB20.5Sr0.5Co205+ocathodeforintermediate-temperature solid oxidef fuel cells," Journal of Power Sources, Volume 194, Issue2, 2009, Pages 815-817.

\section{Conference Papers}

1. Y.Xie, X. Xue, "A modeling study of porous electrode propertyeffects on solid oxide fuel cell performance,"Proceedings ofFuelCell2009, Seventh International Fuel Cell Science, Engineering and Technology Conference, June 8-10,2009 NewportBeach, California.

2. Shi,J. and Xue, X., "CFD analysisofanode-supported solid oxide fuel cells with heterogeneous electrode properties," 34th In temational Conference and Exposition on Advanced Ceramics and Composites, Jan 24-29, 2010, Daytona Beach, FL.

3. Y.Xie, X.Xue, "First principle electrochemical impedance spectroscopysimulation for SOFCs,"FuelCell2010-33101, Proceedings of the ASME2010 Eighth International Fuel Cell Science, Engineering and Technology Conference, June 14-16,2010 Brooklyn, New York, USA.

4. Shi, J. and X. Xue, "Bi-functionally Graded Electrode Supported SOFC Modeling and Fluid Analysisfor Experimental Design,"FuelCell2010-33099, Proceedings of the ASME2010 Eighth InternationalFuel Cell Science, Engineering and Technology Conference, June 14.16, 2010 Brook lyn, New York, USA. 